Georgetown University Law Center

Scholarship @ GEORGETOWN LAW

2019

\title{
International Taxation in an Era of Digital Disruption: Analyzing the Current Debate
}

Itai Grinberg

Georgetown University Law Center, itai.grinberg@law.georgetown.edu

This paper can be downloaded free of charge from:

https://scholarship.law.georgetown.edu/facpub/2145

Taxes, Mar. 2019, at 85-118.

This open-access article is brought to you by the Georgetown Law Library. Posted with permission of the author. Follow this and additional works at: https://scholarship.law.georgetown.edu/facpub

Part of the International Trade Law Commons, Taxation-Transnational Commons, and the Tax Law Commons 


\section{International Taxation in an Era of Digital Disruption: Analyzing the Current Debate}

\section{By Itai Grinberg*}

\section{Itai Grinberg examines the global debate about the allocation of taxing rights with respect to the taxation of cross-border corporate income.}

ITAI GRINBERG is a Professor of Law at Georgetown Law and a member of the Institute of International Economic Law at Georgetown.

\section{Abstract}

The "taxation of the digital economy" is currently at the top of the global international tax policymaking agenda. A core claim some European governments are advancing is that user data or user participation in the digital economy justifies a gross tax on digital receipts, new profit attribution criteria, or a special formulary apportionment factor in a future formulary regime targeted specifically at the "digital economy." Just a couple years ago the OECD undertook an evaluation of whether the digital economy can (or should) be "ring-fenced" as part of the BEPS project, and concluded that it neither can be nor should be.

Importantly, concluding that there should be no special rules for the digital economy does not resolve the broader question of whether the international tax system requires reform. The practical reality appears to be that all the largest economies have come to agree either that a) there is something wrong with the taxation of the "digital economy," or b) there is something more fundamentally wrong with the structure of the current international tax system given globalization and technological trends.

This paper is intended as a limited exploration of the second (or third, or fourth) best. It analyzes three policy options that have been discussed in general terms in the current global debate. First, I consider whether "user participation" justifies changing profit allocation results in the digital economy alone. I conclude that applying the user participation concept in a manner that is limited to the digital economy 
is intellectually indefensible; at most it amounts to mercantilist ring-fencing. Moreover, at the technical level user participation faces all the same challenges as more comprehensive and principled proposals for reallocating excess returns among jurisdictions. Second, I consider one such comprehensive international tax reform idea, loosely referred to by the moniker "marketing intangibles." This idea represents a compromise between the present transfer pricing system and sales or destination-based reforms to the transfer pricing regime. I conclude that splitting taxing rights over "excess" returns between the present transfer pricing system and a destination-based approach is complex, creates new sources of potential conflict, and requires relatively extensive tax harmonization. This conclusion applies equally to user participation and marketing intangibles. If such a mechanism were nevertheless pursued, I suggest that a formulary system for splitting the excess return is the most manageable approach. Third, I consider "minimum effective taxation" ideas. I conclude that, as compared to the other two policy options discussed herein, minimum effective taxation provides a preferable path for multilateral cooperation.

\section{Table of Contents}

\section{Introduction}

I. Background

A. The Decline of the Arm's-Length Standard

B. The Relationship Between the Arm's-Length Standard, Jurisdiction to Tax, and the Attribution of Profits to PEs

C. The Rise of International Tax Unilateralism and the Push to Tax Big Tech

D. U.S. Tax Reform, the BEAT and the GILTI

1. GILTI

2. The Relationship Between GILTI and the Digital Tax Debate

3. BEAT

II. Value Creation and User Participation

III. Where We Go from Here: Destination-Based Income Tax Reform?

A. Background: The Destination-Based Residual Profit Allocation

1. Comparison of DBRPA with Sales-Based FA

B. Destination-Based Residual Marketing Profit Allocation

1. Dividing a Residual Return

Between Marketing-Based and

Other Intangibles

a. A "Two Sided" Valuation Solution? b. A Relative "Capitalized Expenditure" Approach?

c. A "One-Sided" Valuation Solution?

d. A "Formulary DBRMPA" Solution?

2. Problems with Relying on Destination for Income Tax Purposes

a. Inapplicability of VAT Best Practices

i. Destination of Goods

ii. Location of Services

b. Known Solutions Building on Income Tax Administrative Concepts Are Insufficiently Robust

c. Other Methods of Identifying Destination

d. Relationship Between FDII and Any Destination-Based Allocation System

3. Problems with Unitary Approach

4. Conclusions re DBRMPA

IV. Pairing Inbound and Outbound Minimum Taxes?

A. Outbound Minimum Taxes

1. Relationship of Outbound Minimum Taxes to German Royalty Barrier

B. Inbound Minimum Taxes

1. The BEAT That Could Be: A Reverse CFC Rule

Conclusion 


\section{Introduction}

For the University of Chicago Federal Tax Conference in November 2018, I was asked to write a paper "discussing what the U.S. position should be and how the U.S. tax rules should be changed (or not) in reaction to European tax changes such as the proposed gross tax on digital receipts, the digital PE, and the diverted profits tax."

A core tax policy claim some European governments are advancing is that user data or user participation in the digital economy justifies a gross tax on digital receipts, new profit attribution criteria, or a special formulary apportionment ("FA") factor in a future formulary regime. One fundamental question these claims raise is whether there is anything unique about the digital economy. In the BEPS project the OECD undertook an evaluation of whether the digital economy can (or should) be "ring-fenced," and concluded that it neither can be nor should be. But the OECD's conclusion is not stopping some European governments from pursuing proposals that attempt to apply special tax regimes to a limited set of digital businesses. ${ }^{1}$

Importantly, simply concluding that there should be no special rules for the digital economy does not resolve the broader question of whether the international tax system requires reform prompted in part by the digitalization of the economy. Indeed, a debate about this question is ongoing at the $\mathrm{OECD}$. We know more about the contours of that debate today than we did when I was first asked to undertake this paper. The practical reality appears to be that all the largest economies have come to agree either that a) there is something wrong with the taxation of the "digital economy," or b) there is something more fundamentally wrong with the structure of the current international tax system in an era of globalization and digitalization. ${ }^{2}$ Government representatives have now made this plain in multiple public forums. So, one way or the other, we lack a stable status quo. ${ }^{3}$

This paper sets out some considerations for U.S. international tax policymaking and international tax diplomacy in this uncertain environment. To that end, Part I briefly describes four disparate background considerations that should inform our thinking. Part IA describes the decline of the arm's-length standard, which underpinned our historic understandings about how to attribute profits as among entities within a multinational corporation ("MNC"). I argue that internationally the arm's-length standard as we knew it before the BEPS project is largely gone, and has been replaced by an unsustainable concept for profit attribution that I label the bourgeois labor theory of value ("BLTV"). Part IB describes the relationship between the arm's-length standard, jurisdiction to tax, and the attribution of profits to permanent establishments ("PE"). It highlights that under OECD principles, attribution of profits to PEs is accomplished through application of the OECD's transfer pricing guidelines ("TPG"). Part IC recounts various acts of tax unilateralism abroad, often focused on the tech sector, and including the trend toward abandoning historic limits on jurisdiction to tax. Part ID describes the United States' 2017 tax reform in that global context, with a particular focus on the global intangible low-taxed income ("GILTI") and the BEAT.

The remainder of the paper is intended as an exploration of the second (or third, or fourth) best. For purposes of this paper, I therefore do not analyze options that were considered and rejected in the most recent U.S. tax reform, including a destination-based cash flow tax or an integrated corporate tax system, and certain options that never made it into the most recent tax reform debate, such as adopting a VAT.

The discussion is instead limited to three options that have been discussed in general terms in the current global debate. Each of these options preserves a classic corporate tax system that includes an entity-level tax on the normal return to capital. One further important caveat is that in this paper I attempt as best I can to fill in ideas that have been described with a very high level of generality with additional potential content, in order to motivate the analysis.

Part II focuses on the European Commission and Her Majesty's Treasury ("HMT") stated view that user participation should be acknowledged as a source of value creation in the digital economy and concludes that the user participation concept has application well beyond the so-called digital economy. Applying the concept in a manner that is limited to the digital economy is intellectually indefensible; at most it amounts to mercantilist ring-fencing.

The user participation theory does, however, have an important relationship to other more generally applicable proposals for international tax reform. In particular, it involves a shift toward destination-based income taxation, in much the same manner as some other proposals for fundamental international income allocation reform, albeit only for one sector.

At least two more comprehensive and principled proposals to reform the international tax system's attribution of profits are apparently now being considered at the OECD. These respectively are often loosely referred to by the monikers "marketing intangibles" and "minimum taxation." As publicly described, these ideas seem to be at an early stage of development. 
Part III evaluates a version of the "marketing intangibles" idea which I label the destination-based residual market profit allocation ("DBRMPA"). Part IV evaluates a version of a minimum tax system that combines inbound and outbound measures, and which I label "minimum effective taxation."

Importantly, simply concluding that there should be no special rules for the digital economy does not resolve the broader question of whether the international tax system requires reform prompted in part by the digitalization of the economy. Indeed, a debate about this question is ongoing at the OECD.

Part III builds on the discussion about "where we go from here" in transfer pricing provided by Andrus and Oosterhuis in a paper for the 2016 University of Chicago conference. The DBRMPA is related to that conference discussion of two years ago. In particular, it represents a compromise between the present transfer pricing system and sales or destination-based reforms to the transfer pricing system described in the Andrus/Oosterhuis paper. Part III concludes that splitting taxing rights over "excess" returns ${ }^{4}$ between the present transfer pricing system and a destination-based approached is complex. It creates new sources of potential conflict as between sovereigns and as between sovereigns and multinationals. Moreover, some destination specification problems for which solutions do not exist or at least are not widely known would need to be addressed. Finally, the DBRMPA likely requires extensive tax harmonization and information exchange; more so than a minimum tax approach. Importantly all of the above conclusions regarding a DBRMPA apply with equal rigor as technical critiques of user participation. The difference is simply that a DBRMPA applies to the whole economy and therefore-unlike user participation-has some principled basis. If a DBRMPA were pursued, Part III suggests that a formulary mechanism for doing so is the least technically challenging approach.

Part IV builds on the discussion of the GILTI and the BEAT in Part I as well as other discussions of the pros and cons of those provisions in tax forums over the last year.
Part IV postulates that there may be a more sensible path for multilateral cooperation around minimum effective taxation. This approach could be both responsive to the current global international tax debate and build on (and help repair) our 2017 international tax reform. I conclude that a minimum effective taxation approach would be preferable to a DBRMPA.

\section{Background}

\section{A. The Decline of the Arm's-Length Standard}

Article 9 of the OECD Model Tax Convention is intended to ensure that MNCs do not obtain inappropriate tax advantages by pricing transactions within the group differently than independent enterprises would do at "arm's length." More than half of world trade is now intra-firm. ${ }^{5}$ Thus, more than half of world trade is subject to transfer pricing.

Under the arm's-length principle, multinational groups are supposed to divide their income for tax purposes among affiliates in the different countries in which the MNC does business, in a way that is meant to emulate the results that would transpire if the transactions had occurred between independent enterprises. ${ }^{6}$ For most of the last 40 years, the arm's-length principle represented a consensual solution reached among technicians for the problem of allocating tax between different parts of an MNC. ${ }^{7}$ Although the mantra of "arm's length" masked real disagreement, and members of the transfer pricing practitioner community often held the view that there was substantial controversy as to the proper implementation of the arm's-length standard, the range of interpretation was, in practice, reasonably narrow. Major transfer pricing disputes arose with regularity, but they were addressed within a framework that largely respected intercompany contracts and the concept of allocation of risk within a multinational group. ${ }^{8}$

In the last decade, however, the "arm's-length standard" became extraordinarily controversial. ${ }^{9}$ Transfer pricing even became the subject of contentious discussion among high-level elected officials with no tax expertise at all. ${ }^{10}$ Moreover, the so-called "stateless income" 11 narrative became commonly accepted by tax policymakers in almost every developed economy.

As a result, preexisting norms developed by the community of transfer pricing specialists came under heavy and perhaps deserving scrutiny. Views around the level of deference to be given to intergroup contractual arrangements in transfer pricing analyses diverged substantially, the consensus on the scope for recharacterizing intergroup transactions frayed, the consensus on respecting intergroup equity contributions declined. Disputes among 
government officials about whether value creation in crossborder transactions undertaken by multinationals should be attributed to capital, labor, the market, user participation, or government support are now aired routinely. ${ }^{12}$

Enormous political pressures coming from the highest levels of government and the G-20 meant that some sort of outcome on transfer pricing was politically necessary as part of the BEPS project. ${ }^{13}$ Thus, in 2015, the BEPS project in effect endorsed the commonly held idea that the then-existing OECD TPG were broken. However, at the technical level bureaucrats failed to reach meaningful consensus on a clearly delineated alternative. The result was a reliance on high levels of constructive ambiguity buried in many pages of technocratic language in the transfer pricing outputs of the BEPS project. ${ }^{14}$

One phrase that captures this ambiguity is the commitment to "align income taxation with value creation." Everyone agrees on the principle—-but no one agrees what it means. ${ }^{15}$

Nevertheless, if there was one central theme to the BEPS transfer pricing guidance taken as a whole, it was to put great weight for purposes of allocating intangible income and income associated with the contractual allocation of risk on "people functions." The people functions of interest were activities by people who are of sufficiently high skill to engage in the development, enhancement, maintenance, protection, and exploitation of intangibles (the so-called "DEMPE functions") as well as to be able to control financial risks, including those associated with the employment of intangibles. It is these people functions that the post-BEPS TPG treat as "meriting" the allocation of excess returns from intangibles. In contrast, contractual or legal ownership of an intangible is not particularly significant, nor is "routine" labor. ${ }^{16}$ I call this approach to transfer pricing the BLTV.

The labor theory of value asserts that the value of a good or service is fully dependent upon the labor used in its production. This theory was an important lynchpin in the philosophical ideas of Karl Marx. In contrast, conventional capitalist economic theory relies on a theory of marginalism, in which the value of any good or service is thought to be determined by its marginal utility. Moreover, the pricing of a good or service is based on a relationship between that marginal utility, and the marginal productivity of all the factors of production required to produce the relevant good or service. In addition to labor, a key factor of production required to produce most goods and services is capital-including real and intangible assets purchased with capital.

The BLTV attributes profits quite heavily to the labor of certain highly educated workers who occupy upper middle management roles_-roles and backgrounds broadly similar to those who negotiate transfer pricing rules for governments. The theoretical basis in economics for this BEPS transfer pricing settlement is unclear. It turns the Marxian labor theory of value on its head while being inconsistent with the conventional economic view, too. To my mind this feature makes it even less coherent than other possible bases for transfer pricing.

\section{However, the digitization of the economy does force policymakers to confront a basic choice between destination-based corporate income taxation and residence-based corporate income taxation.}

In the 2013 to 2015 period, the BLTV clearly seemed like an attractive alternative theory to various government officials. It addressed the "cash box" problem of multinational income being parked in zero tax places like the Cayman Islands and Bermuda, while attributing income to what the relevant officials viewed as "meaningful" activity.

However, the post-BEPS BLTV version of the OECD's TPG, if implemented in good faith by tax administrations around the world, would effectively provide that an MNC can in various situations save hundreds of millions or even billions of dollars by moving 20 or a 100 key jobs to a low-tax jurisdiction from a high-tax jurisdiction. And many of those jurisdictions-Switzerland, Ireland, and increasingly the UK-are attractive places to live, with talented, high-skill labor pools already in place.

Requiring that DEMPE activities be conducted in tax-favorable jurisdictions in order to justify income allocations to those jurisdictions encourages DEMPE jobs to move to those jurisdictions. This transfer pricing result - that income may be shifted by moving highskilled jobs-is deeply geopolitically unstable. From the corporate perspective, there can be huge incentives to shift DEMPE jobs if enough tax liability rides on the decision. At the same time, large developed economies with higher tax rates simply will not accept an arrangement that sees them losing both tax revenue and headquarters and $\mathrm{R} \& \mathrm{D}$ jobs.

In providing the above critique regarding the BEPS transfer pricing settlement, I do not wish to be misunderstood. Outside the transfer pricing area (BEPS Actions 8-10), I believe the BEPS project had many notable accomplishments. Global best practices and minimum 
standards were developed with respect to important issues like hybridity, interest expense deductions, information reporting, and more. The BEPS project certainly showed how soft law in the international tax space can be quite efficacious. But transfer pricing is sufficiently important that the failure to reach a sensible result in this space casts a shadow over the BEPS project generally. The failure to grapple in a sensible way with the questions raised by transfer pricing is one important reason the post-BEPS environment is characterized by much of the global tax chaos the BEPS project was supposed to prevent. ${ }^{17}$

\section{B. The Relationship Between the Arm's- Length Standard, Jurisdiction to Tax, and the Attribution of Profits to PES}

Tax treaties specify when an enterprise based in one state has a sufficient connection to another state to justify taxation by the latter state. Under Article 5 of the OECD Model Tax Convention, a sufficient connection exists when an enterprise resident in one state (the "residence state") has a "permanent establishment" in another state (the "source state"). The PE threshold must be met before the source state may tax that enterprise on active business income properly attributable to the enterprise's activity in the source state. The PE rule encapsulated in Article 5 thus represents the basic international standard governing jurisdiction to tax a non-resident enterprise.

A shift from our residence-based system to a destination-based corporate income tax, if agreed to by the major economies, is certainly a viable option.

Under Article 7 of the OECD's Model Tax Convention, profits attributable to a PE are those that the PE would have derived if it were a separate and independent enterprise performing the activities which cause it to be a PE. ${ }^{18}$ In 2010, the OECD issued a report on the attribution of profits to PEs. The report concluded that a PE should be treated as if it were distinct and separate from its overseas head office; and that assets and risks should be attributed to the PE or the head office in line with the location of "significant people functions."
The post-2010 OECD approach to attributing profits to a PE is commonly referred to as the Authorized OECD Approach ("AOA"). ${ }^{19}$ This approach is based on the adoption of the 2010 version of the business profits article (Article 7) of the OECD Model Tax Convention. Step one of the AOA leads to the recognition of internal dealings between the PE and its head office. ${ }^{20}$ Then, under step two, the guidance in the OECD's TPG is applied by analogy to determine the arm's-length pricing of the internal dealing between the PE and the head office. ${ }^{21}$ The 2010 report on the AOA made clear that as the TPG were modified in the future, the AOA should be applied "by taking into account the guidance in the Guidelines as so modified from time to time." 22

In the BEPS project, many countries focused on the idea that technological progress (especially the Internet) and the globalization of business have made it easier to be heavily involved in the economic life of another jurisdiction without meeting the historic PE threshold. In the end the BEPS project produced some notable changes to the PE threshold. ${ }^{23}$ These changes to Article 5 of the OECD Model Tax Convention are now being transposed into the global tax treaty network via the multilateral instrument, which itself represents another success of the BEPS project. Importantly, however, the BEPS project concluded that the AOA did not need to be revisited in light of the changes to Article 5.

Fundamentally, the AOA was developed because if associated enterprises in different countries were taxed under the arm's-length standard under Article 9, but PEs were taxed under some other rule under Article 7, distortions between structures involving PEs and structures involving subsidiaries would arise. As a result, the OECD Model Tax Convention attempts to apply the TPG and the arm'slength principle as consistently as possible in both cases. ${ }^{24}$

Applying the AOA means that the PE and its head office are treated like independent enterprises. Note, however, that modern tax treaty PE tests are built to a significant degree on an underlying idea of dependence that differs from dependence/independence of ownership. ${ }^{25}$ Thus, the AOA taxes a PE as if the PE and its head office are independent enterprises, but by definition a dependent agent $\mathrm{PE}$ requires dependence. This paradox is a product of the decision to have the transfer pricing rules trump the PE rules and make the arm's-length standard the central organizing principle. ${ }^{26}$ As a result, in our current legal construct, discussing the attribution of profits to a $\mathrm{PE}$ requires discussing which rules we wish to use to allocate MNE profits generally.

The alternative to the dependency criteria for establishing the existence of a PE is physical presence. Arguably, 
that mechanism for establishing a PE is just a proxy for meaningful presence in the economic life of a jurisdiction through dependent agents. Historically the physical presence rule was also a pragmatic administrative consideration. The physical presence of either an enterprise or a dependent agent of the enterprise was necessary in order to collect tax revenues from a taxpayer. Today, however, the pragmatic consideration is much less important in business-to-business transactions, given the development of reverse-charging type mechanisms and the ability to require a resident business to withhold from a nonresident. Moreover, in the Internet era, it seems to me a losing argument to suggest that large digital firms do not have a meaningful global presence. So the principled debate with respect to jurisdiction to tax and attribution of profits to PEs is just the debate about how to allocate the profits of an MNE among jurisdictions generally. ${ }^{27}$

\section{The Rise of International Tax Unilateralism and the Push to Tax Big Tech}

Many jurisdictions decided quite quickly that they were not satisfied with the BEPS transfer pricing outcomes, at least with respect to specific companies or sectors where they wished to collect more revenue. The marquee actor in this story is the United Kingdom.

In 2015, before the BEPS project had ended, the United Kingdom imposed a $25 \%$ tax on profits deemed to be artificially diverted away from the UK. The Diverted Profit Tax ("DPT") targets instances where, under existing PE rules, an MNC legitimately avoids a UK taxable presence, despite the fact that the MNC is supplying goods or services to UK customers. The UK took the position that the DPT was not covered by the United Kingdom's income tax treaties, and therefore that the PE rules tax treaties specify as to when a state has jurisdiction to tax an enterprise based in another state did not apply to the DPT.

The primary justification for OECD countries recommending and the G-20 launching the BEPS project had been to develop rules-based multilateral reforms that would prevent unilateral actions by the countries participating in the BEPS project. The UK adopted the DPT at the same time that it was helping lead the BEPS project. The UK's decision both to lead a multilateral project that was supposed to set internationally agreed rules that would prevent inconsistent unilateral action, and at the same time unilaterally adopt the DPT, a tax that was not consistent with BEPS, was broadly perceived as a significant blow to tax multilateralism. The decision treated sovereignty as a license for organized hypocrisy. But for the DPT, one could imagine that a more cooperative international tax environment might have evolved out of the BEPS project. ${ }^{28}$
Under the DPT, Her Majesty's Revenue and Customs ("HMRC") can choose which companies it wishes to pursue and to what degree. ${ }^{29}$ Thus, the DPT also struck a blow against non-discrimination principles in international taxation. Indeed, in press interviews UK government officials referred to the DPT simply as the "Google Tax." ${ }^{30}$ The extent to which the DPT is an arbitrary levy on targets of interest to HMRC is well-illustrated by the 12 -fold increase in revenues raised by the DPT between 2015/2016 and 2017/2018. ${ }^{31}$ Twelve-fold increases in revenue without a change in the rate or rules simply do not happen when tax law functions in the normal way. ${ }^{32}$

\section{What analyzing the DBRMPA \\ highlights is that compromise \\ between a destination-based income}

tax and a residence-based corporate

income tax, even principled

compromise, is hard to administer.

splitting the baby is probably

unwise. If policymakers wish for a

destination-based income tax, they

should really try to go all the way

there.

Following the UK's lead, by late 2017, countries as diverse as Australia, Argentina, Chile, France, India, Israel, Italy, Japan, Mexico, New Zealand, Poland, Spain, and Uruguay had taken unilateral actions not limited by or consistent with the BEPS agreements. These measures are generally designed to increase levels of inbound corporate income taxation. Many are structured so that, as a practical matter, they primarily affect U.S. MNCs. Among other examples, in 2016 Australia enacted a DPT-like measure with a $40 \%$ tax rate (also publicly known as the "Google Tax"). India imposed a 6\% "equalization levy" on outbound payments to non-resident companies for digital advertising services. India’s legislation authorized extending the tax to all digital services by administrative action. The Israel Tax Authority announced an interpretation of Israeli law that significantly reduces the level of physical presence necessary for direct taxation of non-resident digital companies. The Korean government is considering amendments to the Korean Corporate Tax Act to 
override Korean tax treaties and treat "global information and communications technology companies" as having a digital Korean PE. Uruguay has enacted, and Argentina is considering, measures similar to those adopted in India. During this same time period the Directorate-General for Competition ("DG Comp") at the European Commission reconceptualized its "state aid" concept in the international tax context, notably by claiming that DG Comp was not limited by the OECD's arm's-length standard in determining whether tax rulings were consistent with EU law. ${ }^{33}$

More recently, governments around the world have been proposing or enacting taxes targeted specifically at digital advertising and online platforms. India went first with its previously-mentioned tax on digital advertising. Then, in September 2017, the European Commission called for new international rules that would alter the application of $\mathrm{PE}$ and transfer pricing rules for the digital economy alone. ${ }^{34}$ Moreover, the Commission argued that until such time as a digital-specific reform of the international tax system was agreed upon, an interim tax based on turnover, or a withholding mechanism, should be imposed on digital platform companies. ${ }^{35}$ The UK followed up on the Commission's digital tax proposals with its own position paper on corporation tax and the digital economy. ${ }^{36} \mathrm{On}$ October 29, 2018, the UK announced the introduction of a "digital services tax" that is based on turnover and is explicitly ring-fenced to hit only large search engine, social media, and online marketplace businesses. ${ }^{37}$ Other unilateral measures focusing on the digital economy have been taken by India (significant economic presence PE), ${ }^{38}$ Israel (digital PE), and others. Like the earlier round of unilateral measures, some of these proposals have been described both in government documents and in the media as taxes targeting "GAFA:" Google, Apple, Facebook, and Amazon. However, the proposals generally are structured to have an impact beyond those four corporations.

Separately, in 2017 Germany adopted its "Act against Harmful Tax Practices with regard to Licensing of Rights." New section $4 \mathrm{j}$ of the German Income Tax Act restricts deductions for royalties and similar payments made to related parties if such payments are subject to a nonOECD compliant preferential tax regime and are taxed at an effective rate below $25 \% .{ }^{39}$ The provision also includes a conduit rule along the same general lines as U.S. code provision section $7701(\mathrm{l}) .^{40}$

In 2017 the UK also opened consultations on a royalty withholding tax proposal, which is now scheduled to be enacted and in force from April 6, 2019. ${ }^{41}$ This withholding tax would generally apply where a non-UK entity making sales in the UK does not have a taxable presence in the UK. Withholding is also extended to payments for the right to distribute goods or perform specified services in the UK. Since there is no UK entity making a payment, the proposal applies almost exclusively to cases where a non-UK company selling to UK customers pays a royalty to a $3^{\text {rd }}$ country jurisdiction. HMT describes the proposal as a step to tax the digital economy, but acknowledges that it has application beyond the digital sector. For example, imagine a Brazilian MNC has a subsidiary in Ireland making sales in the UK and paying a royalty to an entity in the Cayman Islands. Under these proposals, the UK would be trying to withhold from the royalty paid from Ireland to the Cayman Islands. The proposal thus raises the enforcement issues raised in the canonical SDI Netherlands case.

Realistically, more unilateral measures to increase source country taxation, market country taxation, or both are coming. These changes are likely to be somewhat uncoordinated, and sometimes unprincipled. Moreover, these moves toward source or market country taxation are likely to affect "old-line" businesses as well as the digital sector. Tax directors of multinationals in a wide range of industries already highlight that the label "BEPS" is used to justify a wide range of source-country tax adjustments that produce significant tax controversies.

Historically the multilateral international tax architecture was focused on residence country taxation. The international tax architecture around the world appears to be shifting toward more source-based or destinationbased taxation, but that transition is turning out to be very messy. The strategic questions for the United States created by this unsettled state of international tax affairs featured prominently in the final round of discussions about U.S. international tax reform. ${ }^{42}$

\section{U.S. Tax Reform, the BEAT and the GILTI}

By the time of the 2016 elections, there was widespread consensus that the United States needed to reform its aberrant international corporate tax system. Commentators called for a lower corporate tax rate, and a move away from a deferral system and toward the dividend exemption systems that had become an international norm. Other countries had been taking these steps for years, while also increasing their reliance on consumption taxes and decreasing their reliance on corporate income taxes.

Nevertheless, at the outset of 2017, few commentators thought the U.S. political system would successfully bring a tax reform package to fruition. Then, as we all know, the United States surprised the world by enacting tax reform. The international corporate component of the reform was labeled as a shift to a "territorial" regime. However, the 
law enacted actually moved the United States closer to a current worldwide tax system for outbound taxation, instantiated in a regime now known as the "GILTI." At the same time, the United States followed the global trend in enacting unilateral measures intended to strengthen inbound taxation. The United States did so by adopting the "base erosion anti-abuse tax" in new section 59A of the Code ("BEAT").

The GILTI is the main subject of Dana Trier's conference paper and the panel immediately preceding the presentation of this paper at the conference. Therefore, I will not go to any great lengths to describe the GILTI here. Practitioners have also written about the various twists and turns of the BEAT, and I do not propose to reconstruct the full breadth of that discussion, either. Nevertheless, for the sake of completeness a brief background on these provisions is appropriate.

1. GILTI. Code Sec. 951A requires each U.S. shareholder of a controlled foreign corporation ("CFC") to include currently in its gross income its share of GILTI for the year. In very general terms, GILTl refers to a U.S. shareholder's share of a CFC's income above a $10 \%$ return on qualified business asset investment ("QBAI") with respect to everything other than five enumerated categories of CFC income. Those categories are effectively connected income, subpart $\mathrm{F}$ income, income that would be subpart $\mathrm{F}$ income but for the Code Sec. 954(b)(4) high-tax kickout, certain intercompany dividends, and foreign oil and gas extraction income. A U.S. shareholder of a CFC includes in income its GILTI in a manner similar to the inclusion mechanism for subpart F income. GILTI is eligible for a 50\% deduction under Code Sec. 250 (through 2025). Therefore, a minimum effective U.S. tax rate of $10.5 \%$ applies to all GILTI earnings of CFCs of U.S. shareholders. Special rules apply regarding foreign taxes associated with GILTI. Very generally, if a U.S. shareholder that is a domestic corporation elects to take foreign tax credits for a taxable year, all of the foreign taxes associated with GILTI are included in its income as a deemed dividend under Code Sec. 78. However, only $80 \%$ of these foreign taxes are allowed as deemed paid foreign tax credits in the new GILTI foreign tax credit basket. ${ }^{43}$

The New York State Bar Association ("NYSBA") observes that the GILTI can be understood conceptually as a hybrid between "a flat minimum domestic and foreign tax rate on a U.S. shareholder's GILTI inclusions not associated with QBAI (the 'flat rate theory') and the imperfect adding of the GILTI regime onto the subpart F regime (the 'add-on theory')." ${ }^{4}$ One's understanding of which theory should dominate can influence many regulatory decisions. But no matter how one thinks about the regime enacted in the statute (or how the regulations are written), the regime will generally produce at least a minimum $10.5 \%$ combined domestic and foreign tax on a U.S. shareholder's GILTI not attributable to QBAI. ${ }^{45}$ Moreover, given that the concerns in international tax policy are overwhelmingly intangible income-driven, and that the digital sector is "tangible asset light," ignoring QBAI constitutes a reasonable first-order simplification for purposes of this paper.

Finally, it should be noted that most of the complexity entailed by the international tax regulations now being issued by the U.S. Treasury in this area are the product of the QBAI concept, the foreign tax credit basketing system enacted for GILTI, and the legislative design decision to layer a shareholder-level calculation on top of entity-level concepts. None of these features is inherent in or essential to enacting a flat rate minimum tax policy. ${ }^{46}$

\section{The Relationship Between GILTI and the Digital Tax}

Debate. The consequences of GILTI for the international tax debate in the "digital" space should have been profound. When the BEPS project began, the digital economy was a special area of focus because it was considered an important case of so-called "stateless income." ${ }^{\text {"7 }}$

Following the 2017 legislation, the minimum tax rates on foreign earnings achievable for U.S.-headquartered firms have changed. Speaking generally, an intangible driven U.S.-parented multinational simply will not be able to achieve an effective tax rate on their foreign earnings that is below $10.5 \%$. An effective rate of $10.5 \%$ for corporate shareholders (after taking into account the 50\% deduction described above) is comparatively unfavorable to the CFC regimes of most of the major trading partners of the United States, which typically tax CFC earnings in relatively limited circumstances. As a practical matter the consequence is that BEPS leading to stateless incomethe original driver for the entire international tax reform debate-is now a phenomenon that exists only for nonU.S. headquartered multinationals.

Google, Apple, Facebook, Amazon, the four companies specifically targeted in documents issued at various points by the Commission, the French government, and the German coalition agreement, each face a $10.5 \%$ minimum tax on their foreign earnings. Since every EU member state has a dividend exemption system that does not include a minimum tax, and instead provides a $0 \%$ tax rate on foreign earnings when repatriated, companies like Volkswagen, Allianz, Daimler, Siemens in Germany, or BNP Paribas and Carrefour in France do not face a minimum tax burden on their foreign earnings. They 
can, and in some circumstances still do, generate stateless income and achieve $0 \%$ tax on their foreign earnings. That is the reality of current U.S. corporate tax law as compared with the current corporate tax law of the largest continuing members of the EU. Meanwhile, the UK's corporate tax reforms beginning in 2012 were explicitly designed to ensure the ability of UK-headquartered multinationals to achieve a zero rate of tax on foreign earnings by generally exempting those earnings from UK tax.

Therefore, when the Commission or HMT now propose a solution for the digital sector, that proposal is not about addressing low-taxed income or leveling an unlevel playing field - the justifications given for rule changes in BEPS just a few years ago. Rather, the proposals are now clearly about a revenue shift to move tax revenue from jurisdictions of residence to the jurisdictions where digital companies have users. ${ }^{48}$

3. BEAT. The BEAT was enacted to address legislative concerns that the former U.S. international tax regime made foreign ownership of almost any asset or business more attractive than U.S. ownership from a tax perspective, thereby creating tax-driven incentives for foreign takeovers of U.S. firms and foreign acquisition of business units previously owned by U.S. MNCs and financial pressures that encourage U.S. MNCs to "invert" (move their headquarters abroad), produce abroad for the U.S. market, and shift business income to low-tax jurisdictions abroad. Until recently, little policy attention was given to reining in the benefits that U.S. law gives to inbound multinationals that make foreign status more attractive than domestic status. In this regard the United States was a global outlier: in the rest of the world, governments have been focusing their policy efforts almost exclusively on inbound taxpayers that minimize their income in local jurisdictions since the onset of the financial crisis. With the BEAT, the United States took a bold but highly imperfect step to join the global consensus that inbound must be addressed.

New section 59A of the Code imposes an additional tax equal to the "base erosion minimum tax amount" (the "BEAT tax") of "applicable taxpayers." 49 The BEAT tax generally means "the excess (if any) of an amount equal to 10 percent ... of the modified taxable income of such taxpayer for the taxable year, over an amount equal to the regular tax liability ... of the taxpayer for the taxable year, reduced (but not below zero) by [certain credits]. ${ }^{50}$ In other words, the BEAT tax is calculated as the difference between the corporation's regular tax liability and an alternative calculation based on the corporation's modified taxable income.
Modified taxable income for BEAT tax purposes is generally defined as taxable income computed without regard to any deduction with respect to a payment to a foreign related party. ${ }^{51}$ Certain exceptions (notably for certain payments for services) apply. Payments for cost of goods sold ("COGS") also have no effect on the calculation of modified taxable income because, as a technical matter, COGS are a reduction in gross receipts (rather than a deductible payment)..$^{52}$ The characterization of payments, especially with respect to transactions involving bundled services and goods, can therefore affect whether a payment is within the scope of the BEAT provision. The BEAT's "modified taxable income" base is also determined without regard to the base erosion percentage of any net operating loss ("NOL") allowed for the tax year.

Only "applicable taxpayers" are subject to the BEAT at all. To be an applicable taxpayer, a U.S. corporation and its affiliates ${ }^{53}$ must meet certain criteria. ${ }^{54}$ Notably, the U.S. corporation generally must have a "base erosion percentage" of $3 \%$ or higher. This base erosion percentage is generally determined by dividing the aggregate amount of a taxpayer's "base erosion tax benefits" for the taxable year, by the sum of the aggregate amount of the deductions allowable to the taxpayer, plus certain base erosion tax benefits allowable to the taxpayer.

The BEAT has been the subject of cogent critiques by the NYSBA and other commentators. ${ }^{55}$ The key BEAT complications for purposes of this discussion relate to the treatment of foreign tax credits and the base erosion percentage concept. In my view, these two features of the BEAT should be removed.

Most tax credits are disregarded in determining regular tax liability for purposes of the BEAT calculation..$^{56}$ Most importantly, foreign tax credits are disregarded. The treatment of foreign tax credits under the BEAT disfavors foreign taxes paid by BEAT taxpayers relative to any other business expense. In other words, foreign taxes are in effect not even deductible for BEAT taxpayers. In various circumstances, the rule disregarding the value of foreign tax credits for purposes of measuring hypothetical regular tax liability increases the BEAT minimum tax dollar for dollar. ${ }^{57}$ Foreign taxes paid by U.S. MNCs are thus treated almost as if they were equivalent to bribes and payments made to entities in Iran and North Korea. This treatment is not justifiable. Moreover, disallowing foreign tax credits has no clear relationship to base erosion.

Second, if a taxpayer's "base erosion percentage" is 3\% or less, they are not subject to the BEAT. The base erosion percentage is generally determined by dividing the aggregate amount of "base erosion tax benefits" of the taxpayer for the taxable year, by the sum of the aggregate 
amount of the deductions allowable to the taxpayer plus certain other tax benefits allowable to the taxpayer. Since both the numerator and denominator of the base erosion percentage fraction represent gross rather than net concepts, the rule is highly manipulable, and the cliff feature encourages manipulation.

Importantly, the BEAT includes a broad grant of regulatory authority to the Treasury. The provision includes specific authority to prescribe such regulations as may be necessary or appropriate. The BEAT also includes a number of specific grants of regulatory authority. These include providing "for such adjustments to the application of this section as are necessary to prevent the avoidance of the purposes of this section, including through" the use of unrelated persons, conduit transactions, other intermediaries, or transactions designed in whole or in part to characterize payments otherwise subject to the BEAT as not subject to the BEAT, or (quite extraordinarily) even regulations preventing taxpayers from obtaining benefits from substituting payments not subject to the BEAT as drafted with payments that would normally not be subject to the BEAT. ${ }^{58}$ The intent behind the scope of this remarkable grant of specific regulatory authority is not discussed in the legislative history. Nevertheless, the language is sufficiently expansive as to raise the question of whether Congress intended the BEAT to give Treasury authority to reconsider allocation of profits generally for minimum tax purposes.

\section{Value Creation and User Participation ${ }^{59}$}

Academic commentators of all ideological stripes have now explained in multiple articles that the international tax system is not now, and never has been, based on a value creation principle. ${ }^{60}$ Moreover, as I suggested in Part IA, no one entirely knows or agrees on the precise meaning of "value creation." Finally, the consensus academic view is that any exercise to define specific sources of value creation is entirely subjective. ${ }^{61}$

Nevertheless, post-BEPS, various governments often repeat the mantra that "the international tax framework is based on a principle that the profits of a business should be taxed in the countries in which it creates value." ${ }^{62}$ One proposal that features prominently among "value creationists" is known by the label "user participation." It purports to give appropriate credit to user participation in value creation in the digital economy. This idea originated from HMT, was then taken up by the European Commission, and is now being studied by the OECD.

HMT and the European Commission both maintain there is something distinctive about value creation in the digital economy. They focus on the example of a user uploading data on a social media platform to illustrate the importance of user participation in the digital space. The Commission argues that in this case user participation contributes to value creation because users' "data will later be used and monetised for targeted advertising. The profits are not necessarily taxed in the country of the user (and viewer of the advert), but rather in the country where the advertising algorithms has been developed, for example. This means that the user contribution to the profits is not taken into account when the company is taxed." 63

HMT and the Commission also assert there is something special about online marketplaces and other "collaborative platforms," that "generates revenue through matching suppliers and purchasers of a good," or "charges a commission for bringing together supply and demand for assets and possessions owned by individuals. The success of those businesses is reliant on the active involvement of users on either side of the intermediated market and the expansion of that user base to allow the business to benefit from network effects, economies of scale and market power." ${ }^{64}$ In contrast, HMT claims participation of users in non-digital businesses is generally "passive."

Two immediate questions arise with respect to the user participation theory put forth by HMT and the Commission. The first question is whether there is any reason to believe that users only meaningfully contribute to value creation in the context of certain digital platforms. The second is how, across the whole of the economy, one would determine when users contribute to value creation, and to what degree.

If user participation is a meaningful concept, it cannot be rationally limited to information communication technologies. Consider a clinical trial from a user participation perspective: such trials involve a corporation giving thousands of individuals free medicine over a period of years in exchange for those users providing deeply personal medical data, as well as a service to the company-the use of their bodies for purposes of experimentation. The resulting data is monetized by obtaining a patent and customizing products to specific diseases and patient populations. This user data is also required for regulatory approvals, without which the company may not sell anything at all.

The data provided by patients is deeply private biometric and health information. In this sense, the data users provide in exchange for free products in the medical economy is often substantially more extensive and personal than the data that a digital user provides. Moreover, their engagement with the providers of their treatment is often more sustained than a digital user of a social media platform. 
After all, in some cases disengaging from the company (ceasing to supply data in exchange for treatment) might fundamentally impact a drug user's health. In sum, both active user participation and data contribution appear to be part of the medical economy.

The most meaningful objection to the above analogy between user participation in the digital economy and user participation in the medical economy relates to the fact that the medical economy generally does not benefit from either "multisided business models" or network effects. Indeed Commission, HMT, and OECD documents each often highlight these two economic phenomena in describing potential justifications for a special profit allocation for user participation in the digital economy. ${ }^{65}$

Neither multisided business models nor network effects are new economic phenomena, nor are those phenomena limited to the digital platform businesses affected by user participation proposals. Multisided platform businesses are generally defined as businesses that a) offer distinct products or services, b) to different groups of customers, c) whom a "platform" connects, d) in simultaneous transactions. In simpler terms, they are market makersbusinesses that help unrelated parties get together to exchange value. Network effects refer to the phenomenon whereby a product or service gains additional value as more people use it.

Before the advent of the Internet, the classic example of a multisided business model with network effects used in economics discussions involved financial intermediation. Credit card businesses represent one example. On one side of the business consumers are offered convenience and financing, and on the other side merchants obtain a mechanism to receive payment other than in cash. Moreover, the more merchants accept a credit card, the more attractive a credit card is to consumers, and the more consumers hold a credit card, the more willing merchants are to accept the card and its related interconnection fee. ${ }^{66}$ Other "non-digital" multisided business models with network effects include newspapers, traditional broadcast television, video game consoles, financial exchanges, and even farmer's markets (which charge rent to sellers, and allow shoppers to enter the market for free).

Of course a farmer's market has network effects because it is more valuable to buyers and sellers respectively to the extent that there are more farmers and more local shoppers participating. However, the magnitude of the network effect is much greater, and potentially more salient for tax purposes, when the "platform" (the marketplace) involved can intermediate transactions globally. That issue of magnitude is presumably what HMT and the
European Commission think is special-network effects and multisided business models combined with so-called "cross-jurisdictional scale without mass."

Focusing on the issue of large network effects combined with cross-jurisdictional scale without mass brings us to financial exchanges. Network effects are the key feature of successful financial market making, because for transactions to take place there must be both buyers and sellers. Specifically, market liquidity is an important feature in determining transaction costs and making a market attractive to participants, and the number of participants is what determines liquidity. As the number of buyers and sellers on a given exchange increase, liquidity increases, and costs fall. Without enough buyers and sellers, the market literally falls apart.

As an example, consider the Lloyd's insurance marketplace, based in the UK. The vast majority of Lloyd's business involves insuring non-UK risks, often without any physical presence in the jurisdictions where the covered risk exists on behalf of either Lloyd's or the underwriters and syndicates that form the Lloyd's marketplace. ${ }^{67}$ Moreover, the vast majority of the capital in the Lloyd's market does not come from the UK. ${ }^{68}$ But, as Lloyd's itself explains, the certainty provided by the marketplace as well as the network effects from Lloyd's global network of insurance companies, brokers, and coverholders "makes Lloyd's the world's leading (re)insurance platform." ${ }^{69}$ The London stock exchange is another important financial marketplace, albeit one where at least some of the offerings are not as bespoke (and therefore require less data) than is customary at Lloyd's.

Do users somehow participate less "actively" in traditional financial marketplaces when they enter into transactions than they do in online sharing marketplaces? The key participation feature of online marketplaces are reviews and ratings of sellers and buyers.

Much more complex user data is shared among the specialist syndicates, brokers, and coverholders participating in the Lloyd's insurance market than is shared by short-term renters on a vacation rentals platform. ${ }^{70}$ And these market participants interact in more complicated ways than do renters and owners. Moreover, Lloyd's has now created a mandate that syndicates enter into many of their contracts electronically over a digital platform. ${ }^{71}$ So, using Lloyd's as an example, it becomes difficult to see the clear distinction between an insurance intermediation platform and, for instance, the accommodation intermediation platform represented by Airbnb. It is true that historically one business (reinsurance) was globalized 
before the advent of the Internet while the other (home rentals) was not. And historically underwriters sometimes exchanged views offline, while renters often found it hard to exchange views at all. However, now both businesses are globalized, users on both the buy side and the sell side share their views with one another in both industries, and one industry is fully digitalized while the other is working to move in that direction. It seems intellectually unsustainable to claim there is a relevant difference with respect to user participation between the accommodation traded on Airbnb and bespoke products traded electronically in financial markets.

The Internet of Things ("IoT") is likely to make the distinction between businesses with network effects and multisided business models and more "traditional" business even harder to maintain. IoT refers to the network of physical objects embedded with sensors and network connectivity that allows the collection and exchange of data. Such sensors are becoming ubiquitous in the devices we encounter in our daily environment. A large number of Io $T$ applications are being developed in various domains by start-ups, SMEs, and large MNCs alike. ${ }^{72}$

One widely discussed IoT example is the idea of the "connected car." Connected cars are likely to feature seats that face a windshield that is akin to a computer screen. ${ }^{73}$ Trends in automotive research and development involve navigation and entertainment display screens built into the dashboard to offer Internet-based information and media, as well as sensors intended to pick up information from roads and other networked cars. On one model of what constitutes "active user participation," a connected car would have all the components for user participation in place. The user would provide geo proximity data by driving, financial information by leasing, and be in a car that acts as a channel to deliver advertising to a "captive" recipient.

On another model, use of a connected car would not constitute "active user participation" because the user of a connected car would not be actively writing a message or rating a product or service. In that case, however, clicks on a social media platform would also seem to constitute "passive" user participation. It seems inconceivable that "going" to a website or "searching" virtually should be classified as active user participation but going somewhere physically should be classified as passive activity.

Some projections suggest that there will be more than 30 billion Io $\mathrm{T}$ devices in use by $2020 .^{74}$ In addition to connected cars, commercial and industrial applications, driven largely by building automation, industrial automation, and lighting, are projected to account for many of the new connected devices coming into use between 2018 and $2030 .{ }^{75}$ If those projections come to pass, it is hard to imagine that user participation in historically non-digital sectors will not exceed any de minimis user participation threshold.

In sum, it does not seem intellectually defensible to suggest that users only meaningfully contribute to value creation in the context of certain digital platforms, or to think that the boundaries of the idea are clear enough to allow for anything approaching reasonable implementation. Indeed, as articulated thus far it is difficult to view the proposal as anything other than either a) ill-conceived or b) transparently instrumentalist and mercantilist.

But understanding the user participation perspective remains important. For one thing, the user participation proposal highlights the political angle much of Europe brings to the current digital tax debate. Even more importantly, HMT and the Commission have both suggested that when "active user participation" is present, "jurisdictions in which users are located should be entitled to tax a portion of those businesses' profits." 76 HMT wishes to achieve this result using what is in effect a formulary system. ${ }^{77}$ The Commission proposes doing so based on a facts and circumstances arm's-length analysis of the value of user participation. ${ }^{78}$ Either way, these proposals seek to allocate some (although not all) of the excess return of a business to the destination jurisdiction. And that issue-destination-based income taxation-lies at the heart of the intellectual debate about the future of the corporate income tax as applied cross-border.

Indeed, the core of Part III is a discussion of a proposal for allocating excess returns through a reform of the international tax system that would create a hybrid between a destination-based income tax and the present residence-based system. Such a system would, like the user participation proposals, allocate a part of the excess return of a business to market ("user") jurisdictions. Thus, the second key question regarding a user participation proposal, namely, how, across the whole of the economy, one would determine to what degree users contribute to "value creation," is conceptually parallel to the question of how, across the whole of the economy, one would allocate a part of the excess return to market jurisdictions. That is the "bridge" between the user participation proposal and the "marketing intangibles" or "DBRMPA" proposal described in Part III. Importantly, this means that all of the technical and administrative issues that will be described in Part IIIB below also apply in equal measure to any user participation proposal. 
The principled issue is whether, how, and to what degree, across the whole of the economy, law should allocate the excess return of a business to consumer/user/market jurisdictions for corporate income tax purposes. The key difference between the proposal described in Part III and the user participation theory is that the proposal in Part III does not attempt to ring-fence the digital economy. Rather, it tackles this allocation question generally, without resorting to unsustainable and unjustifiable distinctions in business models.

\section{Where We Go from Here: Destination- Based Income Tax Reform?}

This Part considers the "marketing intangibles" or DBRMPA idea that constitutes a compromise between the current transfer pricing system and a destination-basis income tax. This hybrid approach may be under consideration in some form or other at the OECD. My formulation of this approach may or may not be the same as what is under discussion at the OECD, as the proposal has not been publicly described in any detail. However, no matter how a marketing intangibles concept is formulated, certain key issues will have to be addressed. These include how to split excess returns between the current arm's-length system and an allocation to market countries, and how to determine destination so as to split the amount allocated to market countries among such countries.

The DBRMPA described here is a compromise between the present transfer pricing system and a form of destination-based income tax known as a destination-based residual profit allocation ("DBRPA"). The DBRMPA proposal divides intangible returns between those generated by so-called "customer-based" or marketing intangibles and those generated by other (presumably usually "productionbased") intangibles. Residual returns deemed attributable to customer-based or marketing intangibles would be allocated to the market - the jurisdictions where the customers reside. Residual returns deemed attributable to other intangibles would be allocated based on current transfer pricing rules (i.e., the BLTV). Importantly, in this sense the DBRMPA functions in the same way as user participation, but does so across the whole economy, instead of ring-fencing this change based on a cliff effect determined by whether a business is categorized as being "digitalized" or not.

\section{A. Background: The Destination-Based Residual Profit Allocation}

The DBRPA proposal was developed by a group consisting of Alan Auerbach, Michael Devereaux, Michael Keen, Paul Oosterhuis, Wolfgang Schön, and John Vella. The idea is explained in the excellent paper authored by
Joe Andrus and Paul Oosterhuis for this conference in 2016 entitled "Transfer Pricing After BEPS: Where Are We and Where Should We Be Going." Further details appear in a presentation given by Paul Oosterhuis at Oxford University in $2016 .{ }^{79}$ The proposal represents an attempt to move toward a destination-basis corporate income tax system by means that can at least be described as remaining consistent with some of the principles of the current "arm's-length" transfer pricing architecture.

The DBRMPA is fundamentally a compromise between a DBRPA and the current transfer pricing system. Thus, analyzing the DBRMPA first and foremost requires understanding the DBRPA. ${ }^{80}$

The DBRPA proposal is animated by the understanding that the location of consumers is less mobile than the location of booked profits, intellectual property, corporate assets, corporate employees, or any other element of value creation. In this sense it is similar to sales-based FA. However, the DBRPA attempts to separate "excess" or "residual" returns from "routine returns," and provide a normal rate of return to productive functions. The firstorder advantages of a DBRPA are supposed to be reduced incentives to shift income to low-tax jurisdictions, reduced complexity and reduced administrative burdens.

The core idea is to salvage the existing arm's-length system with respect to routine returns, while using a sales-based system to allocate residual returns. How would it work? To allocate excess/residual returns, the DBRPA deems the country in which customer sales take place to be an "entrepreneurial" affiliate with respect to local market sales, and ascribes all "non-routine" profits to that affiliate. ${ }^{81}$ Achieving this result would require MNCs to measure gross revenues by country and by product using some concept of "destination" or "place of supply." Global costs would need to be measured at a product line level, and then either traced or apportioned out to revenues from specific countries.

The DBRPA mechanism for allocating the residual share to the market is quite similar to a cost-sharing approach for allocating income attributed to intangibles. However, instead of allocating the residual profit to an "entrepreneurial risk-taker" in an MNC group defined as the affiliate that owns the intangible property and takes on financial risk (as in contemporary cost-sharing models), the residual profit is instead allocated to affiliates in the respective market jurisdictions. The proposal in effect imposes deemed contractual arrangements to which traditional transfer pricing methods are then applied. As a result, the DBRPA allocates excess returns on a product line by product line basis rather than an entity by entity basis. In doing so it appropriately escapes the "formulary apportionment" label. 
1. Comparison of DBRPA with Sales-Based FA. The most important difference between a DBRPA and salesbased FA is that a DBRPA would modify transfer pricing methodologies so as to allocate only "excess" or "residual" profits to the jurisdiction of sale. ${ }^{82}$ Sales-based FA systems do not necessarily allocate any income to jurisdictions where corporate functions take place. In the United States, our status as a very large market obscures this concern that sales-based FA raises. But consider a small jurisdiction; let's call it Denmark. Whatever the theoretical merits, it is probably hard for politicians to explain to Danish taxpayers that a Danish corporation which exploits a range of local benefits to make outputs that are wholly or almost wholly exported will pay no or almost no corporate income tax in Denmark. The cost-plus markup on productive functions in the DBRPA is somewhat responsive to the concern that sales-based FA provides no revenue to jurisdictions where economic activity takes place. It solves the "Denmark problem" to some degree.

Although DBRPA is not a sales-based FA proposal, in many circumstances DBRPA could produce results that are similar to the residualsales-based formulary apportionment ("RFA") proposal put forth by Avi-Yonah, Clausing and Durst in 2011. RFA would allocate a fixed markup (7.5\% in the Durst et al proposal) on costs to entities that undertake activity within an MNC. ${ }^{83}$ All other profits would then be allocated to the destination/market country.

The key difference between DBRPA and RFA is that DBRPA imposes a destination-basis allocation for residual returns on a product line by product line and individualized country by country basis. ${ }^{84}$ If percentage of gross sales revenue on the one hand and percentage of corporate profit on the other vary significantly by country, DBRPA and RFA would generate different results. ${ }^{85}$ Similarly, if average profit levels vary by product line and some countries generate more revenue for an MNE from high-profit products while other countries generate more revenue for an MNE from low-profit products, DBRPA and RFA would generate different results. ${ }^{86}$

DBRPA requires determining where sales occur. Andrus and Oosterhuis correctly observe that using location of sales to allocate income "raises several particularly difficult issues, ${ }^{81}$ including: the treatment of remote sales, the treatment of sales through intermediaries, the treatment of sales of raw materials, components and intermediate goods, the treatment of capital goods sales and the treatment of services." ${ }^{\prime 77}$ At minimum, addressing these issues would require augmented information exchange and potentially some degree of collection assistance. These issues also have first-order ramifications for DBRMPA, and so are addressed further below. Another important issue discussed below is that, like both sales-based FA and RFA, DBRPA likely requires countries to agree on rules that define the corporate income tax base.

Other technical questions also arise in thinking about DBRPA. ${ }^{88}$ Such issues include the treatment of losses, the treatment of flow-through entities, the treatment of certain financial transactions, and the treatment of M\&A. In addition, financial accounting treatment may be problematic, and there are important questions about the compatibility of these ideas with tax treaties and international trade commitments. These issues were outlined in the 2016 Andrus and Oosterhuis effort. I do not rehash that discussion below, although these concerns may be relevant to a DBRMPA as well.

\section{B. Destination-Based Residual Marketing Profit Allocation}

A DBRMPA has the same starting point as a DBRPA: affiliates of an MNE are compensated for their functions on a cost plus or return on assets basis using arm's-length principles. Unlike in the DBRPA, however, the "residual return" must then be divided between marketing or customer-based intangibles and other intangibles. This division is necessary in order to then allocate income deemed to arise from customer-based or marketing intangibles to the market of destination for the good or service, while allocating the remaining residual return under existing transfer pricing principles.

Going forward in this Part I will use the term "marketing intangibles." There may very well be a substantive distinction between marketing intangibles and customerbased intangibles. For example, in the U.S. core deposits of a financial institution were historically thought of as a "customer-based" intangible, but might not be a marketing intangible. Similarly, the value of a "network effect" might be considered a "customer-based" intangible but not a marketing intangible. ${ }^{89}$ However, in this discussion I explicitly do not intend to invoke such substantive distinctions. I am simply choosing a single term (marketing intangibles) for ease of exposition. ${ }^{90}$

The conceptual motivation for the DBRMPA derives from at least two sources. First, some believe certain export-driven jurisdictions would adamantly reject a DBRPA. However, at least two of the most prominent of these jurisdictions, Germany and Japan, may believe that the intangible value held by their domesticallyheadquartered corporations derives primarily from production intangibles rather than from marketing intangibles. Thus, these jurisdictions (the theory presumably goes) might be willing to accept a DBRMPA. Second, some policymakers may believe that marketing 
intangibles are fundamentally "customer-based," and therefore more appropriately allocated to jurisdictions of destination ("the market") than is income attributable to other intangibles.

Both of these premises are subject to doubt. For purposes of this paper, however, I will set those two questions aside and limit myself to administrative and pragmatic issues associated with the DBRMPA. This drafting decision is not because I'm persuaded by the premises described above.

The DBRMPA raises three basic administrative concerns. First, it retains all of the problems of current transfer pricing law, because with respect to residual returns that are not allocated to the marketing intangibles current law applies. Second, the proposal imposes an inadministrable distinction between residual returns associated with marketing intangibles and other residual returns. Third, since a DBRMPA allocates residual returns associated with marketing intangibles to the market jurisdiction, all the challenges associated with any destination-basis income tax proposal are present in the DBRMPA.

The problems of current transfer pricing law are wellknown, and were also discussed in Part IA. Part IIIB.1 discusses historical evidence suggesting that the distinction between marketing intangibles and other intangibles is not administrable, and also considers various potential solutions to that concern. Part IIIB.2 discusses the difficulties associated with determining destination for purposes of allocating revenues in a destination-basis income tax. There are two sub-issues. First, mechanisms used in the VAT to determine destination do not work in an income tax. Second, solutions to determine destination by building on existing income tax-based concepts are insufficiently robust. Part IIIB.3 describes the difficulties that arise because the DBRMPA relies on unitary tax principles for purposes of allocating costs, but not for purposes of determining revenues. Part IIIB.4 concludes that the DBRMPA, while it seems attractive as a political compromise at 100,000 feet, entails a level of complexity and embedded sources for further conflict as between sovereigns and as between sovereigns and multinationals that is problematic. It also would require a significant degree of international tax harmonization.

\section{Dividing a Residual Return Between Marketing- Based and Other Intangibles. The DBRMPA raises} an important and likely technically irresolvable point of controversy: the extent to which residual returns are attributable to customer-based or other intangible assets.

A legislative definition of "marketing" or "customerbased" intangibles would presumably be required to operationalize a basic DBRMPA proposal. One could certainly imagine such definitions. For example, a statute might define income associated with patents, copyrights, trade secrets, and any other intangible clearly related to product function or composition as "production-based" intangible income, and specify that all other income not allocated to a routine return was "marketing intangible" income. Alternatively, a statute could define marketing intangibles to include trademarks, tradenames, and franchises as well as the value of installed customer bases, expectation of future business from that base, and goodwill and going concern value.

A working legislative definition does not solve the underlying valuation problem. Conceptually the DBRMPA requires valuation of all "marketing intangibles" as distinct from all other intangibles in order to produce a ratio via which all residual income could be divided between marketing intangible income (which in this usage can equivalently be called "customer-based intangible income") and other intangible income.

This issue-distinguishing between customer-based intangibles and other intangibles-is not new for U.S. law. Prior to enactment of the Omnibus Budget Reconciliation Act of 1993, many categories of intangibles were eligible for income forecast depreciation, often on accelerated schedules. ${ }^{91}$ As a result the value of customer-based intangibles as opposed to patents and other intangibles acquired in various transactions had to be determined. Amortization deductions before 1993 depended on the acquirer's ability to establish that an acquired intangible had a limited useful life that could be established with reasonable accuracy and an ascertainable value separate from goodwill, since goodwill was non-amortizable. ${ }^{92}$ Amortizable intangibles were then amortized under various useful lives.

In contrast, Code Sec. 197 spreads amortization over a 15-year straight line period, without regard to their "type." Code Sec. 197 obviates the need to ascertain individual valuations for different categories of intangibles, and greatly diminishes the incentive taxpayers once had to characterize acquired intangibles as assets distinguishable from goodwill and going concern value.

Fred Goldberg, a former Commissioner of the IRS, explained the administrative problem created by prior law to Congress in 1992, shortly after he left the job of Commissioner of the IRS and became the Assistant Secretary of the Treasury for Tax Policy. He testified that the need to allocate basis among purchased intangibles not only resulted in substantial uncertainty and dissimilar treatment of similarly situated taxpayers, but also imposed large wasteful transaction and administrative 
costs on taxpayers and the government. Before 1993, disputes over the amortization of customer-based or market-based intangibles, including but not limited to items such as core deposits held by financial institutions, insurance expirations, and newspaper and magazine subscription lists, produced many prominent, large dollar litigations. ${ }^{93}$ As one author described the problem, "the governance of purchase price allocations to intangible assets [has become] an administrative quagmire and a judicial disaster." 94

For tax years between 1979 and 1987, for all unresolved audit cases (on any issue) in examination, appeals, or litigation as of mid-1989, in fully $70 \%$ of those cases in which taxpayers claimed that an intangible assets had a determinable useful life over which amortization was available, the IRS proposed adjustments and claimed that the assets were in fact goodwill. ${ }^{95}$ Moreover, for that same period, the single category of intangible assets over which this dispute arose most often were customer or marketbased intangibles. ${ }^{96}$ The debate before 1993 regarding acquired intangibles largely focused on distinguishing between customer-based intangibles and goodwill, the latter of which was not amortizable under pre-1993 law. But the core problem was allocating purchase price premia across intangible asset categories generally.

This same issue-whether an intangible is a customer or market-based intangible or some other intangible (goodwill or something else) would arise in a new guise in a regime that distinguishes between "marketing intangibles" and other intangibles. As long as one result is more favorable for the taxpayer on the one hand or the government on the other, or for one government or another, incentives for controversies regarding classification arise. But relative to pre-1993 U.S. law, the difference would be that instead of being limited to cases where intangibles were acquired, the controversy would arise with respect to every single cross-border transaction in which a non-routine return existed. The intangible classification incentive of a foreign sovereign where any DEMPE functions took place and the incentives of the IRS would always be at cross-purposes. To paraphrase Fred Goldberg's 1992 congressional testimony regarding the analogous issue a generation ago, if we go down this path, "[n]o amount of after the fact enforcement and litigation can possibly remedy the situation." ${ }^{97}$ We will have re-created a mess from a generation ago and compounded it exponentially.

a. A "Two-Sided" Valuation Solution? Another key difficulty with a DBRMPA arises from the fact that, like the DBRPA, this is a transactional method. The DPRMPA therefore has the complexity associated with determining profit levels on a product line by product line and countryby-country basis.

However, the DBRMPA differs from the DBRPA in that it requires a profit split of the residual profit being allocated for each transaction between profits attributed to marketing intangibles and other residual profits. A methodology must be chosen to undertake this profit split. ${ }^{98}$ In transfer pricing terms, on first impression a DBRMPA would seem to require application of the transactional profit split method to all transactions, even where only one party makes unique and valuable contributions.

We've spent years in transfer pricing trying to limit the use of the transactional profit split method. The OECD's recent guidance on the application of the transactional profit split explains why: "[a] weakness of the transactional profit split method relates to difficulties in its application." 99 As a result, the OECD perspective is that "where the accurate delineation of the transaction determines that one party to the transaction performs only simple functions, does not assume economically significant risks in relation to the transaction and does not otherwise make any contribution which is unique and valuable, a transactional profit split method typically would not be appropriate." ${ }^{100}$ For the same reason, the OECD maintains that "a lack of comparables alone is insufficient to warrant the use of a transactional profit split." ${ }^{101}$

In various high-profile cases over the years, the application of the transactional profit split produced highly intractable disputes between taxpayers and governments and between competent authorities in governments. One well-remembered example is the IRS transfer pricing dispute with Glaxo SmithKline Holdings (Americas) Inc. \& Subsidiaries ("GSK") for the tax years 1989-2005. ${ }^{102}$ The essence of the dispute was over the level of U.S. profits reported by GSK after making intercompany payments that needed to take into account production intangibles developed by and trademarks owned by its UK parent, relative to the value of GSK's marketing intangibles in the United States. ${ }^{103}$

The facts of the GSK case required coordination between the United States and the UK with respect to what current OECD TPG would describe as a two-sided transactional profit split. The public record suggests the UK government never acceded to the U.S. assertion as to the share of the GSK profits that were attributable to U.S. marketing intangibles rather than UK production intangibles. ${ }^{104}$ The GSK case is particularly well-remembered, and the size of the dispute was unusual, but the basic setup is not unique.

Two-sided transactional profit splits lend themselves to requiring intergovernmental coordination through MAP to avoid double juridical taxation. Even after the BEPS 
project and the advent of the multilateral instrument, mandatory binding arbitration is still available only in a limited set of MAP cases, and the risk of failures of MAP coordination remains high in transactional profit splits. Sometimes, maybe this is just the way it has to be. But why would we want to adopt an international tax system that sets up this exact type of dispute between taxpayers and governments and as between national tax administrations in every case; including in the broad swath of cases where everyone previously agreed the transactional profit split method had no relevance? ${ }^{\text {105 }}$

\section{b. A Relative "Capitalized Expenditure” Approach?} Another potential approach to splitting residual profit between profits being allocated to marketing intangibles and profits being allocated to other intangibles could involve specifying which expenditures contribute to developing marketing intangibles and which expenditures contribute to developing other intangibles. Governments would then presumably establish "useful lives" for various buckets of expenditure. The resulting relative "capitalized values" associated with marketing intangibles as compared to other intangibles would produce a ratio. The ratio would change each year as a result of both new expenditures by the MNC and the operation of whatever "amortization schedule" was adopted for the various buckets of expenditure. The "amortization schedule" would not produce actual deductions; it would simply establish the annual ratio of "marketing intangibles" to "other intangibles." That ratio (as it adjusted each year, presumably on a product line by product line basis), would provide the ratio of excess return to be allocated through the current arm's-length system as opposed to being assigned to market jurisdictions for each specified product line.

Something akin to this approach is said to have been used in some advanced pricing agreements entered into by some multinationals both with the IRS and with foreign tax administrations. But generalizing this approach would be very resource intensive. Moreover, the approach transmutes the debate as to what constitutes a "marketing" or "customer-based" intangible as opposed to other intangibles into a debate as to what costs develop a "marketing intangible" and what costs develop other intangibles (e.g., production intangibles) and what the respective useful lives of such expenditures should be. ${ }^{106}$ It is unclear to me that this represents a meaningful improvement on the basic two-sided DBRMPA method described in Part IIIB.1.a. It certainly highlights the relationship between the problem of relative valuation in a DBRMPA and the useful life issues Code Sec. 197 was enacted to eliminate.

Finally, the relative capitalized expenditure approach is hard to translate into the context of the digital business models that are at the heart of this debate. Which expenditures can be attributed to creating "network effects," and thereby a form of "marketing intangible?" Considered prima facie as an intellectual matter, arguably few or none. But is that an answer that would be globally accepted?

c. A “One-Sided" Valuation Solution? The central problem described in Parts IIIB.1.a and IIIB.1.b arises as a result of the attempt to put relative values on the intangibles associated with "marketing intangibles" as compared to other intangibles. Again, in IIIB.1.a valuing "marketing intangibles" and "other intangibles" respectively is just a mechanism to create the ratio of excess return to be allocated through the current arm's-length system as opposed to being assigned to market jurisdictions. IIIB.1.b, produces the same ratio through a relative "capitalized asset" approach.

Another alternative to resolve the relative valuation marketing intangible/other intangible allocation problem would be to value the excess return that should be ascribed to specifically listed production intangibles. The system could then allocate the residual-that is to say, the excess return remaining after subtracting the return given to non-routine production intangibles- to the "marketing bucket" and assign it to market jurisdictions on a destination-basis.

This one-sided DBRMPA method would avoid the problem described in Parts IIIB.1.a and IIIB.1.b with respect to dividing residual returns between marketing intangibles (the market) and other intangibles (the current transfer pricing system) using a ratio. Instead, one could imagine using a one-sided method by attempting to locate a comparable uncontrolled transaction for non-routine production intangibles, ${ }^{107}$ or by applying a profit indicator, for example a return on costs associated with specified production intangibles (or some other net profit indicator).

This latter approach (a one-sided profit indicator approach) is similar to the OECD's "transactional net margin method" ("TNMM") (known in the United States as a comparable profits method), but with one important difference. The OECD TPG specify that a TNMM is only supposed to be applied when one of the two parties owns and controls all the relevant non-routine intangibles.

MNCs would be incentivized to adapt tax planning to a one-sided DBRMPA, which would value the return to "marketing intangibles" as a residual after a return is ascribed to non-routine production intangibles. In a one-sided DBRMPA world with DEMPE rules (i.e., the BLTV) for the allocation of the return ascribed to production intangibles, MNCs would seek to a) locate their production intangibles in low-tax jurisdictions and b) 
maximize the valuations for their production intangibles. Nevertheless, because excess returns are so large for the world's leading companies, the one-sided methodology DBRMPA, which ascribes a specified return to production intangibles and gives everything else to the market, would likely allocate most (high) excess returns to the market/ marketing intangibles.

A one-sided DBRMPA methodology that values only specified production intangibles is intellectually distinguishable from a DBRPA. However, as a practical matter the one-sided DBRMPA produces a result that asymptotically approaches the outcome in a DBRPA. It also has all the issues associated with determining destination in DBRPA, without achieving one of the DBRPA's virtues, which is eliminating the administrative problems associated with current transfer pricing law.

It should also be noted that the reason the DBRPA is not currently under consideration internationally does not appear to be related to whether it is normatively defensible. Rather, the DBRPA is not part of the debate because it is politically unpalatable to a number of major jurisdictions and other constituencies that oppose allocating all or most of the residual return from intangible assets to market jurisdictions. The one-sided DBRMPA methodology could be politically unpalatable to those same jurisdictions and other constituencies.

Finally, one should note that the one-sided DBRMPA methodology described above is in some sense the inverse of the "digital investment" idea put forth by Wolfgang Schön. ${ }^{108}$ Schön's idea treats "digital investment" as the functional equivalent of the "marketing intangible" in the DBRMPA. Schön suggests that market-specific digital investment should be measured, and the return associated with that investment should be valued using a TNMMtype approach and allocated to market jurisdictions. How that measurement would be accomplished is not entirely clear, but Schön's idea is quite interesting. It could be integrated into the current transfer pricing system more easily than any DBRMPA concept. And the digital investment concept certainly would not asymptotically approach a DBRPA. It is unclear whether the Schön's proposal is being considered as a mechanism to implement the marketing intangibles idea. However, the terminology used by Schön and the terminology that has been used publicly to date in the marketing intangibles discussion do not overlap.

\section{d. A "Formulary DBRMPA" Solution? Some might} acknowledge the problems of allocating between production intangibles and marketing intangibles based on either a "two-sided" or a "one-sided" transfer pricing method, and then suggest that the issue should simply be resolved by agreeing a percentage allocation to the market. For instance, governments could agree that distinguishing between market intangibles and other intangibles was not systematically administrable, and therefore the excess return should just be divided based on fixed percentages (50/50) between market jurisdictions and the existing arm's-length standard (the BLTV). A formulary approach clearly does address the allocation problems described above with respect to the DBRMPA as between marketing intangibles and other intangibles. Moreover, it does so without asymptotically approaching a DBRPA.

However, formulary DBRMPA likely raises the issues traditional FA raised in the United States. In other words, because activity is mobile, but sales are not, jurisdictions would be incentivized to abandon a 50/50 split and move in the direction of a $100 \%$ allocation to destination.

U.S. states use an FA system to determine their taxable share of U.S.-source corporate profits. The basic mechanics of an FA system, in which intercompany transactions are generally ignored, are thus familiar to most U.S. tax lawyers. A generation ago U.S. state corporate tax apportionment formulas were based on a weighted average of the shares of sales, payroll, and assets in the state. ${ }^{109}$ However, these formulas create an implicit excise tax on the factors used in the formula. ${ }^{110}$ As a result, the three-factor formula discourages MNCs from investing in assets or generating employment in high-tax locations.

Over the years the states of the United States shifted (in inconsistent ways) away from three-factor apportionment toward sales-only apportionment factors to gain a competitive advantage in attracting tangible investment and jobs. ${ }^{111}$ In the international setting, with higher tax rates than state income taxes and fewer coordination mechanisms to limit competition, most serious commentators agree that this dynamic would be more intense. Moreover, customers are much less mobile than employment in the cross-border setting, so economic theory would suggest that a sales-based apportionment should produce fewer economic distortions than an apportionment formula that took location of employment into account. ${ }^{112}$

Formulary DBRMPA would crystallize the problems of the BLTV. Research consistently shows that high skilledDEMPE-capable-labor is the most mobile form of labor globally (certainly more mobile than the payroll and assets factors of traditional FA). Meanwhile consumers are quite immobile. The dichotomy between an apportionment factor that is immobile and an apportionment factor that is highly mobile, with fixed percentages to each, creates an implicit excise tax on the mobile factor. That reality would likely push countries in the direction of unilaterally choosing a $100 \%$ allocation to the immobile factor 
(the location of the consumer), in order to eliminate the implicit excise tax on high-skilled jobs that the 50/50 split would create, just as U.S. states over-weighted sales and abandoned the payroll factor to encourage job creation in their jurisdictions. Moreover, in the international system, even more than at the level of the U.S. states, it is not clear what enforcement mechanisms exist to ensure that countries abide by an agreed 50/50 split. Bilateral tax treaties are not well-suited to enshrining such an approach.

The one potential solution I see to the pressures created by the formulary DBRMPA's implicit excise tax on DEMPE jobs in higher-tax jurisdictions is to abandon the BLTV. Governments could decide to revert to pre-BEPS TPG for the part of the excess return attributed to other intangibles and allocated under transfer pricing rules. In that world, contractual allocations of risk would be more fully respected and income shifting for the "other intangibles" portion of excess returns would be somewhat easier than under current law. But shifting income would not require shifting well-paying (and highly mobile) jobs out of higher tax jurisdictions. Reverting to the pre-BEPS TPG therefore would reduce the otherwise inevitable pressure for countries to unilaterally move from a DBRMPA to a $100 \%$ allocation of the excess return to the market jurisdiction.

\section{Problems with Relying on Destination for Income Tax}

Purposes. In any system that allocates part of the return to the market (in other words, any "destination-basis" system) the tax burden is meant to rest in the jurisdiction of the final consumer, rather than the jurisdiction of residence of any intermediaries in the supply chain. The economic rationale for this result is that the final consumer is thought to be the least mobile factor. Thus, from a theoretical economics perspective, a destination-basis system is less economically distortive than other more mobile bases for assessing corporate tax. ${ }^{113}$

However, if the administrative mechanism for measuring the location of sales does not conform to the location of the final consumer, this justification for attempting to tax at destination is undermined. Importantly, multinationals can easily structure their transfer pricing arrangements to book sales income in a jurisdiction that is not the jurisdiction of residence of the final consumer and are incentivized to do so if they can lower their tax burden as a result.

The U.S. international income tax system has been cognizant of this category of issue for decades; it is at the heart of both the 20th century understanding of Code Sec. 482 and the 1962 foreign base company sales income rules.

For the same reason, every destination-basis income tax proposal relies on a concept of destination separate and apart from the contractual decision MNCs make about where to book sales. Andrus and Oosterhuis, as well as other commentators, in effect suggest that concepts for determining destination that have evolved outside the United States for purposes of implementing the valueadded tax might be modified for purposes of administering a DBRMPA. ${ }^{114}$ The VAT does effectively establish destination by means of proxies and administrative solutions in the consumption tax context in most cases. The difficulty is that the mechanisms the VAT uses for this purpose simply are not amenable to implementation in an income tax. ${ }^{115}$

a. Inapplicability of VAT Best Practices. The VAT generally resolves the issue of determining destination using the credit-invoice mechanism. Two of the most important features of the credit-invoice mechanism are taxation on gross amounts and imposition of tax on every transfer, both intra-firm and inter-firm.

An income tax cannot adopt the credit-invoice mechanism for one key reason: income taxes tax net income, rather than gross revenues. In an income tax cross-border business input purchases are generally deductible. In contrast, the VAT establishes destination in large measure by providing cross-border business input purchases a treatment that is the equivalent of non-deductibility. ${ }^{116}$

i. Destination of Goods. For tangible goods, VAT laws generally assess VAT using frontier or border controls. ${ }^{117}$ Imported goods are in effect treated as having the destination of the jurisdiction where they clear customs. VAT is assessed on the full value of the good as it enters the jurisdiction. VAT laws then free exports of VAT through a combination of non-inclusion of proceeds and a refund mechanism for VAT previously paid. As a result, the VAT avoids the difficulties a destination-basis income tax would have with cross-border sales through third-party intermediaries.

The reason third-party cross-border intermediation does not obscure destination in the VAT is that the intermediary pays a full tax on its purchases, and has the full amount refunded on re-export. Exports are not included in the tax base, and then a tax based on the sales price of the good is collected at the jurisdiction of (further) destination. A similar result applies with respect to importation of intermediate inputs (whether raw materials, components, or intermediate goods) that are subsequently exported as part of a different tangible good, and (thanks to expensing) even with respect to capital goods that are purchased to allow for the manufacture of other products for export. ${ }^{118}$ In all cases the credit-input system thereby moves the tax burden to the final buyer.

This VAT system for ensuring that tax is collected at destination only works because the system taxes on a 
gross basis and refunds on every intra-firm and inter-firm transfer. An income tax cannot adopt this basic element of the credit-invoice mechanism as it operates in cross-border situations and remains a tax on net income. As a result, the VAT does not provide useful guidance for resolving problems of destination of goods in an income tax system.

ii. Location of Services. Determining the destination of cross-border trade in services and intangibles more generally has been a key issue in reforming the VAT for the 21 st century. ${ }^{119}$ Since there are no customs controls to impose the VAT at the point of importation on services and intangibles, creating administrable proxies for the destination principle in services and intangibles is challenging. The OECD has developed special guidelines for determining the jurisdiction of taxation for international supplies of services and intangibles over the last decade that attempt to reflect the destination principle.

Determining the location of services raises especially difficult issues in the MNC context. ${ }^{120}$ In many cases, MNC service recipients utilize the services of a service provider in multiple jurisdictions. The country that the services are billed to can become a mechanism for manipulation in a DBRMPA.

Charge-out mechanisms of the kind used in today's income tax system can and do conceptually resolve the problem of determining the destination of services an $\mathrm{MNC}$ recipient receives and uses in multiple locations in the VAT context. ${ }^{121}$ However, the difficulty raised by this solution for tax administrations in the DBRMPA context is different and should not be trivialized. Tax administrations would need to audit service recipients to determine whether charge-outs had been made appropriately in order to inform their audit of the service provider. While charge outs can be a subject of audit in today's income tax system, tax administrators never need to ask whether charge outs by an unrelated party change the tax result for a separate, unrelated taxpayer. The level of internal coordination such a system would require of government auditors simply does not exist today within tax administrations.

\section{b. Known Solutions Building on Income Tax Administrative Concepts Are Insufficiently Robust.} As noted above, sales through third-party distributors would raise substantial avoidance and/or enforcement issues for a DBRMPA. Since the administrative features of the VAT cannot help, other anti-abuse rules would be needed in a DBRMPA to address the tax incentive to structure operations to have customers purchase products through a third-party distributor in a low-tax jurisdiction. Most likely some type of look-through rule would be required. ${ }^{122}$ However, making a look-through rule work would require reporting by third party distributing purchasers. Andrus and Oosterhuis imagine implementation of this sort of system in the context of single-factor sales apportionment. ${ }^{123}$

Getting buy-sell arrangements with third-party distributors to be treated equivalently to related party distribution arrangements or third-party agency distribution arrangements would be challenging. In theory, a DBRMPA would also need similar look-through rules to allocate revenue from sales of intermediate inputs to third-party manufacturers. Ideally these sales would be allocated on a look-through basis based on the country of sale of the end good into which intermediate goods are ultimately incorporated. However, because this structure is infeasible, Andrus and Oosterhuis recommend treating the place where the goods are incorporated into products of the purchaser as the location of sale. ${ }^{124}$ The sale of capital goods raises a more extreme version of the same problem - these are in effect the sale of intermediary goods with a long useful life the value of which is then embedded in end consumer goods and services.

Andrus and Oosterhuis suggest that to prevent rampant abuse, we would need to distinguish between "real" manufacturing and mere re-importation or packaging (this would backstop the look-through rule for distributing purchasers). As they wrote " $[\mathrm{t}]$ he location, for example, of the final packaging or labeling of products can too easily be manipulated if a significant tax advantage results." They then suggest the contract manufacturing rules (which distinguish manufacturing from repackaging) might be used to address this concern.

Those familiar with the difficulties in administering and unintended planning engendered by the contract manufacturing rules might be concerned about adopting a facts and circumstances test for all cross-border transactions, rather than the occasional instance of foreign base company sales income. However, the primary problem is a deeper one: in this case the jurisdiction in which a tax administration would need to audit the question of whether real manufacturing had occurred would often be a jurisdiction in which the MNC under audit has no physical presence. And, as with the location of service use discussed in IIIB.2.a, tax administrations would again be in the position of auditing one business to figure out where taxing rights lie for the profits of an unrelated corporation. Absent a radically improved and streamlined environment for both information exchange and international tax administrative assistance, how are the arising enforcement questions supposed to be addressed? Licensing arrangements and franchising structures raise 
parallel but-from an audit perspective-perhaps more complicated questions than those described above for third-party intermediary sales. ${ }^{125}$

c. Other Methods of Identifying Destination. There may be mechanisms outside historic VAT or income tax practice to identify the destination of some goods and services. Two examples that come to mind are pharmaceutical products and technology that has an IP address. In the pharmaceutical industry for non-tax regulatory reasons businesses generally must keep track of the destination of their products even when those products are being distributed by third-party distributors. An IP address can be used as a proxy for location, so a DBRMPA could potentially treat goods that have an IP address as having the destination associated with their IP address.

The question that then arises is whether destination can be determined using such non-tax proxies for most, some, or only a low percentage of goods and services that generate excess returns. The answer to this question is unclear. What is certain is that the destination of all goods that generate excess returns is not determinable based on piggybacking on non-tax regulatory rules or relying on IP addresses.

d. Relationship Between FDII and Any DestinationBased Allocation System. Interestingly, the IRS and the U.S. Treasury are likely to put all the above-discussed concepts for determining destination to the test. New section 250 of the Code ("FDII") in effect establishes a preferential tax rate for income derived by domestic corporations from serving foreign markets. The statutory rules require determining the foreign portion of deduction eligible income. This amount includes income derived from the sale of property to any foreign person for a foreign use. It also includes income derived in connection with services provided to any person not located within the United States, or with respect to property that is not located in the United States. Thus, the destination of both goods and services must be determined in order to implement the new FDII rules of Code Sec. 250. The IRS and the Treasury will need to write regulations describing how taxpayers should make these determinations in the coming 12 months in order to implement the FDII regime. Any multilateral organization or foreign sovereign evaluating a proposal for a DBRMPA would therefore be well-advised to evaluate the regulatory output of the IRS and the Treasury in this regard.

3. Problems with Unitary Approach. As discussed earlier, a DBRMPA relies on the DBRPA with respect to the portion of the excess return of the MNC allocated to marketing intangibles. The DBRPA in turn is not a formulary system, because it measures returns at a product line level and provides jurisdictions "credit" for higher prices. However, escaping the formulary label does not equate to escaping the related "unitary" label. The DBRPA calculates most revenues at a country level, but it calculates costs on a global consolidated basis, just like the "unitary" aspect of FA.

An important downside of global consolidation is that it requires a common measure of taxable income across jurisdictions. In other words, one needs a single measurement of apportionable income. That is the "unitary" aspect of FA. DBRMPA may not require a common measure of gross income, but it would require common rules regarding costs. The most obvious category of costs that need common allocation rules are indirect costs. The problems of indirect cost allocation are familiar to U.S. practitioners from the foreign tax credit system and our current debates about the GILTI. A DBRMPA would need globally agreed rules about analogous difficult issues. ${ }^{126}$

Moreover, for the DBRPA to work well, schedules for depreciation or amortization of tangible and intangible property, treatment of original issue discount-and perhaps even issues like the method used for inventorying costs or the treatment of fines and penalties-would ideally be standardized across jurisdictions. As Julie Roin explained a decade ago with respect to FA, unitary systems become inadministrable if global costs must be measured for purposes of determining income in each jurisdiction, but each jurisdiction has its own rules with respect to when those global costs are taken into account. ${ }^{127}$

These issues with the "unitary" dimension of FA are well-trodden ground. What observers may not appreciate is that the DBRMPA does not avoid those issues. Indeed, because the DBRMPA requires allocating indirect costs on a product line basis rather than a $\mathrm{QBU}$ basis, the unitary concerns that require tax harmonization to address may be more extensive than under FA.

4. Conclusions re DBRMPA. The DBRMPA combines many of the administrative problems of a residual apportionment system and an arm's-length system in an attempt to produce a political compromise. That political compromise allocates part but only part of the residual return to market jurisdictions. Replacing the current international tax rules with this system would entail substantial institutional transition costs in the United States and elsewhere. ${ }^{128}$

Adopting a system that combines the issues of a residual apportionment system based on destination with the issues of an arm's-length system reduces the stakes associated with the challenges of each part of the new combined system if 
and only if the relative share of the excess return allocated to each part of the new combined system is clear. In this regard, a relative valuation-based DBRMPA recreates the administrative quagmire we had in the United States for valuing acquired intangibles prior to 1993, and expands it to every cross-border transaction involving an intangible. ${ }^{129}$ In contrast, a "formulary DBRMPA" would resolve this issue by agreeing an arbitrary percentage split of excess returns so as to allocate a set percentage of the excess to market jurisdictions and the remainder to the current arm's-length standard. However, the formulary DBRMPA may be subject to the same dynamic that manifested itself in connection with traditional three-factor FA in the United States. In other words, jurisdictions are likely to have economic incentives, revenue incentives, or both to abandon the agreed split and move toward a larger allocation to the market.

Separately, any DBRMPA method-whether "twosided," "one-sided," or "formulary" - would face the same issues associated with international tax base harmonization that apply to unitary taxation systems, as well as the issues associated with determining destination without a credit-invoice system. Finally, all versions of the DBRMPA would maintain the problems of the current arm's-length system for transfer pricing on the other intangibles side of the marketing intangibles vs. other intangibles divide.

\section{Pairing Inbound and Outbound Minimum Taxes?}

This section presents and evaluates a combination of inbound and outbound minimum taxes as a solution to the current debate over transfer pricing and the allocation of taxing rights as among jurisdictions. Minimum taxes include traditional CFC-based solutions, which rely on relative immutability of corporate residence, and newer ideas that combine outbound and inbound minimum taxes. Such ideas appear to have entered the OECD debate. "Minimum effective taxation" is also an issue that Germany has recently raised at the most senior levels in European Union policy discussions.

Notably, the GILTI and the BEAT could respectively be described as an attempt to have outbound and inbound minimum taxes, or as an attempt to ensure minimum effective taxation. In this Part IV, I will suggest that the GILTI and the BEAT can be reimagined to suggest a workable alternative for the medium-term future of the international tax system.

I expect the United States will continue to describe the GILTI and the BEAT with our current acronyms. However, the reconceived system I describe below is perhaps better described as a combination of an outbound minimum tax and something like a "reverse CFC" rule. ${ }^{130}$ The basic concept would be to pair some outbound minimum tax regime (a reformed GILTI) with defensive measures that would only be applied to multinationals parented in countries that do not impose a qualifying outbound minimum tax.

\section{A. Outbound Minimum Taxes}

The GILTI is now highly familiar for the participants at this conference. At the highest level, the GILTI requires a U.S. shareholder of CFCs to pay a minimum aggregate U.S. and foreign tax on its share of the earnings of its CFCs on a current basis. Unlike other dividend exemption systems, the structure of the regime imposes tax on most $\mathrm{CFC}$ income, but does so at a lower rate than domestic income.

As a practical matter the United States is likely to maintain some form of this outbound minimum tax regime over the medium term. At the present time the Republican party believes it has renewed American competitiveness with its corporate rate cut and hopes to protect the basic structure and rates. Meanwhile, Democrats are proposing to raise the corporate income tax rate and the GILTI rate along with it, but have not suggested altering the basic architecture of the regime. That political playing field is unsurprising given that at a 50,000 feet level one can describe the GILTI regime as the Obama Administration proposal to "Impose a 19 Percent Minimum Tax on Foreign Income," 131 just enacted at Republican rather than Democratic rates.

Although the basic architecture of an outbound minimum tax is likely to be a stable feature of U.S. international tax law, the technical details of that construct are subject to change. The 2017 legislation is legislatively unstable in the sense that various provisions expire by their own terms between 2021 and 2025. It is politically vulnerable to revision, because it was enacted via a party-line vote. Finally, it is technically unstable for reasons having to do both with how some provisions are difficult to administer and others may create unintended incentives. ${ }^{132}$

A few examples of political and technical instability of specific features of the current GILTI construct are worth mention. At the political level, Democrats are focusing on the QBAI regime, which exempts a small portion of CFC income from the minimum tax, as creating (unintended) incentives for offshoring tangible investment and related jobs. ${ }^{133}$ Meanwhile, at the technical level, Dana Trier's paper correctly highlights the complexity created by the QBAI regime, as well as the problems created by the QBAI regime's interaction with the treatment of debt. ${ }^{134}$ Separately, many commentators view the GILTI's reliance 
on the existing foreign tax credit and subpart $\mathrm{F}$ mechanics to be administratively inadvisable. There are likely more elegant ways to impose a minimum tax than building a system based on calculations at the shareholder level using rules written for entity-level calculations. ${ }^{135}$ It also is not clear why elements like foreign base company sales income, foreign base company services income, and Code Sec. 956 are necessary components of a minimum tax regime.

I view the combination of a stable basic architecture (an outbound minimum tax regime) and flexibility as to features and technical/mechanical details of the regime as an opportunity for meaningful multilateralism. ${ }^{136}$ From a U.S. perspective, the pragmatic reality is that GILTI may be reformed to function more effectively, but the basic minimum tax concept seems unlikely to be repealed over the medium term. From a non-U.S. perspective, the key political fact is that the United States was historically the biggest impediment to a floor to tax competition. Now the United States has in effect embraced such a regime, without necessarily settling on the details in any permanent way. For countries that have wanted a floor on corporate tax competition and felt the United States was an obstacle to such a result, the unsettled state of GILTI is an opportunity for meaningful and potentially efficacious dialogue.

Two non-American sovereigns that may find a minimum tax proposal attractive are Germany and Japan. It is important to understand why: these are export-driven economies. To the extent source becomes defined as destination, which is the trend we see in the other proposals discussed in this paper, these countries' national interest is to find an alternative to a destination-based income tax system. They and other export-driven economies might also find minimum tax systems attractive to the extent that they are concerned that the incidence of a destination-based income tax is more similar to that of a consumption tax than it is to a residencebased corporate income tax. The most viable alternative to a destination-based income tax is a multilaterally agreed inbound/outbound minimum tax regime that supports a version of the residence-based system.

A minimum tax regime that undergirds residence-based taxation is based on concepts that all currently exist in the law of multiple countries. Therefore, it should be easier to agree on and implement than a shift to destinationbasis taxation. Moreover, such a regime is more objective than trying to ascribe relative value to different kinds of intangibles.

One important problem with any outbound minimum tax regime is that it applies only to tax-resident MNCs, and therefore creates incentives to redomicile. Outbound minimum taxes lower the benefits to a resident MNC eroding the domestic tax base. However, to the extent the United States, or any other country, imposes such a tax, and no other country does the same, the country or countries imposing the outbound minimum tax on resident MNCs discourage corporate tax residence and encourage foreign tax domiciliation for multinational enterprises. Senator Portman's Permanent Subcommittee on Investigations study entitled "Impact of the US Tax Code on the Market for Corporate Control and Jobs" persuasively showed that under prior U.S. law "foreign acquirers that hail from more favorable tax jurisdictions are able to create value simply by restructuring the affairs of the U.S. target companies to improve their tax profile." 137 The United States understandably does not want to be in that world, and other countries would not want to be, either. I testified to Congress about evidence that an important medium-term result of pressures for redomiciling MNCs out of the United States by tax-driven acquisitions of U.S. firms by foreign firms would be fewer high-quality jobs for U.S. workers. ${ }^{138}$ The same would hold true for any country that unilaterally adopted an outbound minimum tax without appropriate defensive measures.

Importantly, multiple countries adopting an outbound minimum tax for resident multinationals alone also would not in and of itself solve the problems associated with cross-border M\&A to escape that taxpayer-unfavorable residence country tax net. Without a "defensive measure," all it takes is one viable corporate headquarters jurisdiction to defect and choose not to have an outbound minimum tax for the dynamic favoring acquisitions by tax-favored MNCs to take hold. For that reason, given the fungibility of tax residence for business units (which can be acquired), new businesses (which can incorporate initially abroad), and multinationals as a whole (which are routinely acquired in cross-border M\&A transactions) simply differentiating tax burdens based on tax residence, without measures to discourage avoidance of a basic residence tax burden, is untenable as a policy option.

\section{Relationship of Outbound Minimum Taxes to} German Royalty Barrier. In 2017, Germany enacted the Act against Harmful Tax Practices with regard to Licensing of Rights (German EStG 4j). This provision of German law restricts the tax deduction of royalties and similar payments made to related parties if such payments are subject to a non-OECD-compliant preferential tax regime and are taxed at an effective rate below 25\%. ${ }^{139}$ This rule has a quite targeted scope, but it evolved from a more general German interest in proposals to encourage or ensure minimum effective taxation. The concept of encouraging minimum effective taxation at a general level, rather than on an item-by-item basis, continues to 
be of interest to German policymakers, including at the finance minister level. ${ }^{140}$ Importantly, the German idea of minimum effective taxation as it has developed in EStG 4j would appear to reflect a country-by-country conception of minimum effective taxation. ${ }^{141}$

\section{B. Inbound Minimum Taxes}

The U.S. Congress was cognizant of the problems associated with taxing resident multinationals in a harsher way than non-resident multinationals when it enacted the 2017 Act. The "Unified Framework for Fixing Our Broken Tax Code" discussed the importance of "rules to level the playing field between U.S.-headquartered parent companies and foreign-headquartered parent companies." ${ }^{142}$ In reporting the BEAT to the Senate floor, the Senate Finance Committee explained that "the current U.S. international tax system makes foreign ownership of almost any asset or business more attractive than U.S. ownership ... creating a tax-driven incentive for foreign takeovers of U.S. firms ... [and] has created significant financial pressures for U.S. headquartered companies to re-domicile abroad and shift income to low-tax jurisdictions." ${ }^{143}$ The Senate Finance Committee's explanation went on to explain that the BEAT was supposed to be an administrable way to meet the promise of the framework to level the playing field.

Unfortunately, the BEAT as enacted does not appear to have met this goal. However, the concept of using an inbound tax to defend residence-based taxation is quite rational. Importantly, the defense of an outbound minimum tax would work best if undertaken via multilateral coordination.

1. The BEAT That Could Be: A Reverse CFC Rule. Four high-level changes would be required to convert the BEAT into a useful inbound base erosion prevention mechanism that also encourages foreign sovereigns to adopt outbound minimum taxes. First, the BEAT would need to be amended so as not to apply to multinationals tax resident in a jurisdiction that imposed a qualifying minimum tax regime. The definition of a qualifying outbound minimum tax would presumably follow the contours of a multilateral agreement. Second, the reformed BEAT would need to be limited to actual base-eroding payments. Most importantly this would mean repealing the disallowance of foreign tax credits and NOLs in present law BEAT. Third, the base erosion percentage limitation would need to be excised. Finally, the BEAT would need to be expanded to cover at least the value of intangible property embedded in goods, or perhaps to cover goods in their entirety. As explained below, the last of these is viable if the purpose of the reformed BEAT were to incentivize other jurisdictions to adopt qualifying outbound minimum taxes, rather than to raise revenue.

The inbound regime ("BEAT 2.0") described above could be accurately described as a "defensive measure." The base amount would still be determined by taking the taxpayer's taxable income increased by certain base erosion items. As in the current regime, taxpayers would multiply the BEAT base amount by a given percent of the BEAT base. If that amount exceeded their otherwise-applicable U.S. tax liability, they would pay the difference between the BEAT amount and their regular tax liability.

However, unlike the current BEAT, this regime would apply only to multinational groups that were not subject at the parent level to an (internationally-recognized) qualifying outbound minimum tax. As a result, countries whose multinationals operate extensively in the U.S. market would have an incentive to adopt qualifying outbound minimum taxes. The incentives in this regard would be much stronger if the United States and the European Union and/or Japan were to take such steps in a coordinated fashion. In a multilaterally agreed minimum tax regime with coordinated defensive measures, MNCs would have strong incentives to remain headquartered in key jurisdictions that had qualifying outbound minimum taxes and were thus part of the new international consensus.

Various criticisms of this approach are available. Let me address just three. First, this approach would require some degree of agreement with respect to the acceptable outer boundaries of outbound minimum tax regimes. Minimum standards with respect to an outbound minimum tax regime represent a certain degree of tax harmonization. Some might fear this would represent a slippery slope toward even further tax harmonization, and that such constraints on tax competition are inappropriate. However, I would suggest to such critics that tax sovereignty is a basic interest of national sovereigns, and that a small step in the direction of coordinated rules may not in this case be a particularly slippery slope.

Moreover, note that the minimum tax regime likely requires much less tax harmonization than the DBRMPA. Inbound minimum taxes used as defensive measures to backstop the outbound minimum tax regime require determining some effective tax rate for the outbound regimes of jurisdictions that formally impose an outbound minimum tax. Otherwise countries could adopt an outbound minimum tax at the appropriate rate on a very narrowly defined base.

But note that the harmonized base definition issues are actually less extensive than in the DBRMPA. Unlike in a DBRMPA (or user participation), in the minimum tax structure the national rules that determine the base from 
which the effective tax rate is measured only matters with respect to the question of whether a national defensive measure is imposed. As a result, the pressures for countries to agree on a shared definition of the appropriate tax base are low. In the minimum effective taxation regime, the base only matters for the purpose of measuring the effective tax rate imposed in another jurisdiction, rather than for purposes of actually splitting up the tax base. As a result, inconsistent national definitions are fine within some wide margins. In contrast, in the DBRMPA and under user participation, the absence of base harmonization can have consequences in every case, because both of those approaches are unitary tax systems. Consistent definitions are needed to split up a base and therefore avoid double taxation. As a result, the pressures to harmonize are higher.

Second, Part IIIB.1 highlights why it is difficult to write regulations that separate embedded intangibles from the overall value of a tangible good in an administrable way. Sales of products containing embedded intangibles present a challenge for any inbound base protection rule that is meant to be WTO-compliant while raising revenue; rather than acting as an incentive for other countries to adopt a regime that is exempt from the inbound base protection rule/defensive measure. ${ }^{144}$

In contrast, if the inbound base erosion/defensive measure rule applies only to multinationals that are not subject to a qualifying outbound minimum tax regime, and if (for example) the United States, the European Union, and perhaps Japan have all adopted such regimes, then "rough justice" that erred on the side of inclusion in destination country tax bases would not be a problem. ${ }^{145}$ Indeed, onerous rough justice would help ensure widespread adoption of qualifying outbound minimum taxes. As more jurisdictions adopted qualifying outbound minimum taxes, the treatment of COGS in cross-border transactions with corporations' whose parent entity was tax resident in a jurisdiction without a minimum tax would become ever less important. ${ }^{146}$

Third, some might suggest that the minimum tax solution would not stop some sovereigns from separately enacting unilateral measures to ring-fence and tax large U.S. tech firms participating in the digital economy. I have sympathy for this critique. We are living through a mercantilist and politically charged moment in international economic law (and the United States is not exempt from this characterization). In the current environment, some sovereigns do seem to want a shift of the "digital" tax base, rather than to ensure a single level of tax on corporate income. The minimum tax proposal does not affect a shift of the tax base from residence to destination, and does not serve a mercantilist end in the digital sector.
Thus, some sovereigns might take unilateral measures to accomplish their desired ends with respect to the digital sector on top of a minimum tax. Indeed, this concern may motivate the marketing intangibles proposal.

However, given that the United States already has a GILTI and is unlikely to repeal it in the medium term, I do not believe the "but it won't stop other countries' digital proposals" critique substantially changes the U.S. policy calculus. Rather, if other sovereigns see redeeming features in the basic outlines of the American status quo, that outcome is in the national interest of the United States. This conclusion does not change if it turns out that multilateral agreement on a minimum effective taxation regime does not also completely stop unilateral efforts by some sovereigns to target the U.S. tech sector. No proposal (including the marketing intangibles proposal) can fully stop such efforts in any case; the political reality abroad that views the U.S. tech sector with distrust is simply too strong. What is important is that an agreement to implement a minimum tax block a multilateral agreement on a digital-only proposal, and also that the foreign countries most interested in a minimum tax outcome commit (including on a bilateral basis) not to pursue digital-only measures. ${ }^{147}$ In other words, although the tech sector is an important U.S. national interest, it is clearly not the only U.S. national interest in the field of international taxation. Rather, our broadest interest should be to stabilize the international tax system generally, ensure that its architecture remains principled, provide certainty for all of our businesses, and bring our new international tax system more closely into alignment with international norms.

Although a multilateral agreement on a minimum effective taxation regime would not necessarily stop every foreign sovereign from enacting tech-specific tax proposals, it would likely discourage many sovereigns from doing so. To provide a simple example, if the German government were to agree to a minimum tax proposal as a solution to the digital tax question, and commit not to enact a digitalonly proposal, it seems unlikely they would renege over the medium term. In my judgment the diplomatic and technocratic political culture of Germany is not such that it would agree to a solution to the digital issue that involved a minimum tax multilaterally, and then shortly thereafter enact a digitally-focused tax. A similar observation might be made about many governments (consider Japan for example). If the European Commission were to sign on to a minimum effective taxation agreement to settle the digital tax debate, it is also unlikely that the letter of the agreement would be abandoned. In that particular case, from a U.S. perspective having both EU member states and the Commission commit to an agreement is important. 
The United States should insist at the OECD that the Commission be an independent party to any agreement.

To address any concerns about individual countries behaving perfidiously, the United States should consider including a punitive measure in its reformed inbound minimum tax (BEAT 2.0) to discourage the imposition of particularly destructive taxes. For example, in my view today's gross basis turnover taxes on digital business represent a relatively transparent mercantilist effort to target U.S. firms. U.S. law could be structured so as to apply the reformed BEAT to jurisdictions that imposed taxes targeted at U.S. MNCs, even if they adopted a minimum tax regime. As a statutory matter one could use Code Sec. 891 as a model in this respect. Such a tool would be perceived to have legitimacy internationally if it were tied to a multilateral agreement on minimum taxation. International legitimacy (even if not complete acceptance) should be an important consideration for those of us concerned with reestablishing stability in the broader international economic law environment. ${ }^{148}$

Finally, one might be concerned that the United States itself might want to abandon the minimum tax at a future date. The United States could unilaterally overcome its fiscal challenges and obtain fiscal leeway to lessen its reliance on our economically inefficient corporate double tax by adopting a new revenue source, such as a VAT. At that juncture a multilateral minimum tax regime would function as an unwelcome constraint. However, a new revenue source is not in the offing at this time in the United States. Moreover, it seems unlikely that the political process will soon sanction reducing corporate tax rates by increasing individual income taxes. As a result, anti-base erosion measures will probably continue to be needed over the medium term.

\section{Conclusion}

The international tax system that emerged after World War II had the important advantage of being nestled within a broader world order that, in Henry Kissinger's classic formulation, "had the advantage of uniform perceptions." 149 Countries accepted that the United States led the post-war international economic order of the free world. Almost as a minor corollary, countries generally accepted that the United States led the development of the transfer pricing regime, too.

In contrast, few observers would claim that today's international economic climate features uniform perceptions. The current state of international tax affairs reflects the broader disarray.
One important goal in this difficult environment should be to reestablish some stability to the international tax regime. Among other things, doing so could contribute to the broader goal of stabilizing our system of international economic law more generally.

If medium-term international tax stability is a goal, any answer to the questions raised by the digital economy cannot be limited to any definition of the digital economy, because no corporate international tax problem is unique to the digital economy. Moreover, the features of the digital economy that proponents of a digital-only solution might point to are gradually expanding to encompass the bulk of the economy.

However, the digitization of the economy does force policymakers to confront a basic choice between destination-based corporate income taxation and residence-based corporate income taxation. A shift from our residencebased system to a destination-based corporate income tax, if agreed to by the major economies, is certainly a viable option. But moving to a DBRPA would require significantly higher levels of information exchange and collection assistance than currently exist. More fundamentally, a shift all the way to a destination-based corporate income tax presently seems politically implausible.

Indeed, the current debate internationally does not include a full move to destination-based corporate income taxation as an alternative. Instead there are two proposals that in effect split the baby between destination-based corporate income taxation and residence-based corporate income taxation. These are the user participation theory and the DBRMPA.

The latter "compromise" proposal, the DBRMPA, is principled and, at the 100,000-foot level, may appear politically attractive. It does change the balance of allocation of taxing rights. However, the DBRMPA creates a new set of administrative challenges for which we may not have solutions, while leaving the problems of the current transfer pricing system in place, and adding a new source of fundamental controversy-the appropriate split of excess returns between the market and the current transfer pricing system. These issues could play out as between governments and between governments and MNCs with respect to every cross-border transaction. What analyzing the DBRMPA highlights is that compromise between a destination-based income tax and a residence-based corporate income tax, even principled compromise, is hard to administer. Splitting the baby is probably unwise. If policymakers wish for a destination-based income tax, they should really try to go all the way there.

That said, if policymakers consider the compromise that is the DBRMPA, they should abandon the notion 
of measuring the relative value of marketing and nonmarketing intangibles and accept a simple formulary split between the two residual return categories. It seems to me that in a DBRMPA system, a formulary approach, ideally backstopped by mandatory binding arbitration, is the only way to control the extent of tax controversy. Note, however, that there is currently no international law mechanism that would easily ensure that countries would respect an agreement to a specific allocation of the excess return between marketing intangibles and other intangibles. Bilateral tax treaties are not well-suited to enshrining such an approach; a multilateral treaty (not the MLI of the BEPS project) might be needed. ${ }^{150}$

In contrast to destination-basis corporate income taxation, a minimum tax regime that undergirds residencebased taxation is based on concepts that all currently exist in the law of multiple countries. Therefore, it should be easier to agree on and implement than the DBRMPA, because it does not require tackling all the issues involved in a shift to destination-basis corporate income taxation. A minimum tax regime also (perhaps counterintuitively) requires less extensive international coordination than a DBRMPA. Finally, in a multilaterally agreed regime that included both outbound and inbound minimum taxes, MNCs would have strong incentives to remain headquartered in key jurisdictions that had qualifying outbound minimum taxes. Thus, the weakest point of a residence-based system-redomiciliation and tax-driven cross-border M\&A-would be addressed. Compared to a partial move to destination-basis corporate income taxation, undergirding the residence-based regime with outbound and inbound minimum taxes seems both less disruptive and more administrable.

What is the mechanism for getting there? Success will require discussions around both substance and process to take place at the OECD. Americans must be aware that it will not be the sort of discussion the United States tended to have at the OECD a generation or two ago. The United States no longer is the uncontested leader of the capitalist world, and it does not have an uncontested leadership position in international tax, either. Rather, the best hope in the 21 st century is to use the OECD in international tax the way Metternich used the Congress of Vienna in European military affairs in the 19th century - as a mechanism to overcome quite significant differences in perspective via a balance of power, and in the process (re)build legitimacy, shared values, and a stable equilibrium.

\section{ENDNOTES}

* This article was written for and the topic of discussion at a panel presentation at the 71st Annual University of Chicago Federal Tax Conference. The panel included the author, U.S. Treasury Deputy International Tax Counsel Brian Jenn, John Stowell and Steve Edge, and was moderated by Jim Barry. I thank Pamela Olson and Michael Plowgian for comments on an earlier draft. Oscar Velutini provided excellent research assistance. Any errors are my own.

1 See, e.g., HM Treasury, Budget 2018 Digital Services Tax (Oct. 29, 2018) https://assets.publishing.service. gov.uk/government/uploads/system/uploads/ attachment_data/file/752172/DST_web.pdf.

2 See Organisation for Economic Cooperation and Development (OECD), Tax Challenges Arising from Digitalisation-Interim Report 2018 (2018) www.oecd-ilibrary.org/content/ publication/9789264293083-en; remarks of Brian Jenn at OECD-USCIB 2018 tax conference (all major economies believe either the first or the second of the options). Stephanie Soong Johnston, Official Previews Coming OECD Digital Economy Work, 90 TAX NOTES INT'L 1329 (June 11, 2018).

3 For instance, David Bradbury of the OECD suggested the question of whether issues in the international tax system were limited to the "digital economy" or were more pervasive was at the core of the current OECD debate in his remarks at the International Fiscal Association
(IFA) annual conference in Seoul in September. See Stephanie Soong Johnston, OECD Makes Headway on Long-Term Answers to Tax Digital Economy, 91 TAX NOTES INT'L 1164 (Sept. 10, 2018); Stephanie Soong Johnston, News Analysis: Geeking Out: Digital Taxation Debate Goes Viral at IFA Congress, 92 TAX NOTES INT'L 19 (Oct. 1, 2018).

4 The term "super-normal return" has an understood meaning in economic theory. The term "excess return" does not. I view the returns for which taxing rights may be reallocated in a DBRMPA to be related to but not always the same as the "super-normal return" concept in economics, and so I use the term "excess returns" going forward in this paper.

5 "More than half of U.S. imports from its main non-NAFTA trading partners (with the exception of China and Italy) are also intra-firm transactions. In contrast, U.S. exports to its main non-NAFTA trading partners are predominantly arm's-length-53-65 percent of U.S. exports to large European Union and Asian countries (France, Germany, Japan, Korea, Netherlands, and United Kingdom ...) fit this description." World Bank, Arm's-Length Trade: A Source of Post-Crisis Trade Weakness, Global Economic Prospects Special Focus, 2 (June 2017) http:// pubdocs.worldbank.org/en/222281493655511173/ Global-Economic-Prospects-June-2017-TopicalIssue-Arms-length-trade.pdf.
6. See, e.g., OECD, OECD/G20 Base Erosion and Profit Shifting Project, Aligning Transfer Pricing Outcomes with Value Creation, Actions 8-10-2015, 9 (2015) https://doi.org/10.1787/9789264241244en [https://perma.cc/25E8-UCKY] [hereinafter "BEPS ACTIONS 8-10"]. The arm's-length principle requires that transactions between associated enterprises be priced as if the enterprises were independent, such that the pricing reflects what third parties operating at arm's length would agree upon with one another.

John Neighbour, Transfer Pricing, Keeping It at Arm's Length, OECD Observer, 29 (Apr. 21, 2002) www.oecdobserver.org/news/archivestory. php/aid/670/Transfer_pricing:_Keeping_it_ at_arms_length.html. Of course, important academic critiques and alternative proposals existed before the onset of the BEPS project. See generally, Reuven Avi-Yonah, Splitting the Unsplittable: Toward a Formulary Approach to Allocating Residuals Under Profit Split, Univ. of Michigan Pub. Law \& Legal Theory Working Paper Series, Paper No. 378 (2013) (proposing that the OECD use formulary apportionment to allocate residual profit of the "profit split method").

8 See Matthias Schroger, TRansfer PrICInG: NeXT Steps in the International Debate, Tax Policy Challenges in the $21^{\text {st }}$ Century, 310-312 (Karoline Spies \& Raffaele Petruzzi eds., 2014). Whether one views that outcome as good policy or not, the relatively clear intellectual boundaries for 
these disputes were an outgrowth of the fact that discussion of transfer pricing was limited to tax administrators and other specialists.

9 See, e.g., Reuven S. Avi-Yonah, Between Formulary Apportionment and the OECD Guidelines: A Proposal for Reconciliation, 2 WORLD TAX J. 3, 3 (2010) (arguing that while debate quieted with regard to the arm's-length standard after the adoption of the 1995 regulations and OECD guidelines, the arm's-length standard is unworkable and should be replaced by formulary apportionment); David Spencer, Senior Adviser, Tax Justice Network, Statement by the Tax Justice Network (Mar. 21, 2012, 5:07 AM) http://taxjustice. blogspot.com/2012/03/tin-statement-ontransfer-pricing.html (asserting that the “OECD's theory of the arm's-length principle no longer applies to multinational enterprises which are highly integrated").

10 See generally Stephen Timms, Fin. Sec'y to Treasury UK, Address at the OECD Tax \& Development Conference (Jan. 27, 2010); G-20, Cannes Summit Final Declaration-Building our Common Future: Renewed Collective Action for the Benefit of All (Draft of November 4) (Nov. 4, 2011) www.g20.utoronto.ca/2011/2011-cannesdeclaration-111104-en.html; see also Arun Jaitley, Hon. Fin. Minister, India, A Tax Vision for India, Peterson Institute for International Economics (Apr. 16, 2015).

11 Ed Kleinbard deserves credit for naming the phenomenon and writing the most well-read article about how U.S. MNC international tax planning in the pre-BEPS era worked. See generally Edward D. Kleinbard, Stateless Income, 11 FLA. TAX REV. 699 (2011). However, his U.S. outbound centric view created real difficulties for the United States as a matter of international tax diplomacy. U.S. tax reform is highlighting the extent to which foreign multinationals, especially those headquartered in Europe, have been achieving stateless income with respect to revenues earned in the United States for many years. Unfortunately, no European academic has emerged who is willing to publicize and generalize about aggressive tax planning by European MNCs in the manner Ed did for U.S.-headquartered MNCs.

12 See generally Mindy Herzfeld, Input Needed on Transfer Pricing Drafts, 77 TAX NOTES INT'L 392 (Feb. 2, 2015); China International Tax Center/IFA China Branch, Comments on Discussion Draft on the Use of Profit Splits in the Context of Global Value Chains and other Related Transfer Pricing Issues (Feb. 6, 2015). U.S. officials, for example, have bemoaned this phenomenon in multiple public appearances.

13 See, e.g., comments Marlies de Ruiter, Interview: OECD's de Ruiter Says Forthcoming Changes to Transfer Pricing Guidelines Achieve Correct Balance, 24 TAX MGMT. TRANSFER PRICING REP. 775 (Oct. 15, 2015) [hereinafter "de Ruiter Interview Comments"].

14 See generally BEPS ACTIONS 8-10, supra note 7; see also Michael L. Schler, The Arm's-Length
Standard After Altera and BEPS, 149 TAX NOTES 1149 (Nov. 30, 2015) (discussing ambiguities in the revised transfer pricing guidelines associated with attributing income to various forms of activity, control of risk, or something else).

15 Public presentations offer an illustration of this disagreement: the national delegates and OECD officials that participated in negotiations of the revised transfer pricing guidelines began providing conflicting interpretations of what those guidelines meant almost immediately after the OECD's new transfer pricing guidelines were released. Compare de Ruiter Interview Comments, supra note 14 with comments of Brian Jenn, quoted in Ryan Finley, Transfer Pricing Report Obscured by Terminology, 80 TAX NOTES INT'L 229, 230 (Oct. 19, 2015).

16 See BEPS ACTIONS $8-10$, supra note 7 , ๆ $16.42-6.46$.

17 Cf. The Global Tax Environment in 2016 and Implications for International Tax Reform: Hearing Before the H.R. Comm. on Ways \& Means, $114^{\text {th }}$ Cong. (2016) (Testimony of Itai Grinberg, Associate Professor, Georgetown University Law Center) https://waysandmeans.house.gov/wpcontent/uploads/2016/02/20160224fc-GrinbergTestimony.pdf.

18 OECD, Model Tax Convention on Income and on Capital: Condensed Version 2017, art. 7 (2007) www.oecd-ilibrary.org/content/publication/ mtc_cond-2017-en [hereinafter "OECD Model Treaty"].

19 Not all countries adopted the AOA; as such the attribution of profits to PEs and various countries' interpretations and practices with respect to Article 7 have continued to vary considerably.

20 See Commentary to Article 7, para 2 of the OECD Model Treaty (para 16 et seq).

21 The OECD agrees that this basic principle applies regardless of whether a tax administration has adopted the AOA as explicated in the 2010 Report on the Attribution of Profits to Permanent Establishments. See OECD, Additional Guidance on the Attribution of Profits to Permanent Establishments, BEPS Action 7, 7 (2018) www.oecd.org/tax/transfer-pricing/ additional-guidance-attribution-of-profits-topermanent-establishments-BEPS-action-7.pdf [hereinafter "OECD Additional Guidance"].

22 OECD, 2010 Report on The Attribution of Profits to Permanent Establishments, ๆ10 (July 22, 2010) www.oecd.org/tax/transfer-pricing/45689524. $p d f$.

${ }^{23}$ These changes primarily involved ensuring that commissionaire arrangements could not be used to avoid a PE and modifications to the rules on specific activity exemptions. The latter change was viewed by the OECD as being "particularly relevant in the case of digitalised businesses." See, e.g., OECD Additional Guidance, supra note 22, at 7 .

24 See Commentary to Article 7, para 2 of the OECD Model Treaty, para 16 ("the basic approach incorporated in the paragraph for the purposes of determining what are the profits that are attributable to the permanent establishment is therefore to require the determination of the profits under the fiction that the permanent establishment is a separate enterprise and that such an enterprise is independent from the rest of the enterprise of which it is a part as well as from any other person ... that faction corresponds to the arm's length principle which is also applicable, under the provisions of Article 9 , for purposes of adjusting the profits of associated enterprises.")

25 The PE concept of dependence has been with us since the PE test was first developed in the League of Nations, before the adoption of the arm's-length standard. See generally Richard J. Vann, Tax Treaties: The Secret Agent's Secrets, 3 BTR 345 (2006).

26 Id.

27 I acknowledge that there are enforcement challenges associated with requiring smaller businesses without physical presence to pay tax in a jurisdiction, but I do not view that as a first-order issue.

28 Note also the inclusion of a digital services tax (DST) in the UK budget of October 29, 2018. The DST represents another instance of UK unilateralism in the midst of a multilateral project in which it claims to be a fully committed participant. HM Treasury, Budget 2018 Digital Services Tax (Oct. 29, 2018) https://assets.publishing. service.gov.uk/government/uploads/system/ uploads/attachment_data/file/752172/DST_web. pdf.

29 Dan Neidle et al., The UK Diverted Profits Tax: Final Legislation Published, Clifford Chance, Mar. 25, 2015, www.cliffordchance.com/briefings/2015/03/the_uk_diverted_profitstaxfinallegislatio.html.

30 It is still known by that moniker. Vanessa Houlder, "Google tax" Take Swells to $1281 \mathrm{~m}$ as Levy Starts to Bite, FINANCIAL TIMES, Sept. 13, 2017, www.ft.com/ content/4f7aed86-989f-11e7-a652-cde3f882dd7b.

31 See generally HM Revenue \& Customs [HMRC], Transfer Pricing and Diverted Profits Tax statistics, https://assets.publishing.service.gov.uk/ government/uploads/system/uploads/attachment_data/file/729876/Transfer_Pricing_and_ Diverted_Profits_Tax_statistics.pdf (estimating an increase in the "DPT Yield" from $£ 31 \mathrm{~m}$ in $2015 / 16$ to $£ 388 m$ in $2017 / 18$ ). DPT charging notices raised $57 \%$ of the revenue HMRC attributed to the DPT in 2017/2018. The remainder was raised by what HMRC referred to as "behavioral change," the central element of which was "additional Corporation Tax paid as a result of HMRC intervention to ensure that profits earned in the UK are taxed in the UK." That is to say, HMRC threatened to charge DPT and instead a company "voluntarily" opted to pay more UK corporation tax.

32 Officials from the OECD and the IMF, as well as the canonical Vogel treatise, generally define taxes as legally compulsory and unrequited payments to a government that do not provide a specific economic benefit. Moreover, to qualify as a tax under these definitions, the required 
payment must be a result of law of general applicability that is reasonably clear in its application. See, e.g., Werner Haslehner et al., Klaus Vogel on Double TAXation Conventions, Art. 2, at 26 (Ekkehart Reimer \& Alexander Rust eds., 4th ed., 2015); Ken Messere et al., Tax Policy: Theory and Practice in OECD Countries 240 (2003); Ruud De Mooij \& Michael Keen, Taxing Principles: Making the Best of a Necessary Evil, 51(4) Finance \& Development, Dec. 2014. So, to ask a provocative question-does the DPT meet that test? Note that after France enacted a DPT-like tax, the French constitutional council struck the tax down on the basis that it gave the tax authority too much discretion to selectively target individual taxpayers, and therefore was not constitutional under French law. See Conseil constitutionnel [CC] [Constitutional Court] decision No. 2016-744 DC, Dec. 29, 2016 (Fr.) www.conseil-constitutionnel. $\mathrm{fr} / \mathrm{sites} / \mathrm{default} /$ files/as/root/bank_mm/ decisions/2016744dc/2016744dc.pdf; see also Davide Anghileri, France's Diverted Profits Tax Ruled Unconstitutional, MNE TAX (Jan. 4, 2017) https://mnetax.com/frances-diverted-profittax-ruled-unconstitutional-18873.

33 In the Belgian state aid case, the Commission wrote that, "for any avoidance of doubt, the arm's length principle that the Commission applies in its state aid assessment is not that derived from Article 9 of the OECD Model Tax Convention and the OECD TP Guidelines, which are nonbinding instruments, but a general principle of equal treatment in taxation falling within the application of Article 107(1) of the Treaty, which binds the Member States and from whose scope the national tax rules are not excluded." Commission Decision of 11.1.2016 on the Excess Profit Exemption State Aid Scheme SA.37667 Implemented by Belgium, C(2015) 9837 final, para 150, http://ec.europa.eu/competition/state_aid/ cases/256735/256735_1748545_185_2.pdf.

34 Communication from the Commission to the European Parliament and the Council: A Fair and Efficient Tax System in the European Union for the Digital Single Market, 9, COM(2017) 547 final (Sept. 21, 2017) https://ec.europa.eu/taxation_customs/sites/taxation/files/communication_taxation_digital_single_market_en.pdf.

35 Id., at 10

36 That position paper was released after tax reform was introduced in the U.S. House and U.S. Senate, but before the 2017 Act passed.

37 See HM Treasury, Budget 2018 Digital Services Tax (Oct. 29, 2018) https://assets.publishing.service. gov.uk/government/uploads/system/uploads/ attachment_data/file/752172/DST_web.pdf.

38 See PricewaterhouseCoopers LLP, India Budget 2018: Aiming for the Bullseye, 28 (Feb. 2018) www. pwc.in/assets/pdfs/budget/2018/aiming_for_the_ bullseye_pwc_union_budget_2018_booklet.pdf.

39 See Einkommensteuergesetz [EStG] [German Income Tax Act], §4j; see also, e.g., EY, German Parliament adopts legislation on limitation of tax deduction of royalties and tax exemption of restructuring gains (May 2, 2017).
40 Id. ("If (i) the recipient of the payments or (ii) another party related to the German payer incurs expenses for license rights from which the rights derive that are licensed to the German payer, and the recipient of those payments benefits from an unqualified IP regime, then the deduction of the German licensee's payments are denied to the extent the ultimate payment recipient faces an effective rate below $25 \%$.")

41 See www.gov.uk/government/publications/ offshore-receipts-from-intangible-property/ income-tax-offshore-receipts-in-respect-ofintangible-property.

42 International Tax Reform: Hearing Before the S. Fin. Comm., 115th Cong. (2017) (testimony of Itai Grinberg, Professor of Law, Georgetown University Law Center) www.finance.senate. gov/imo/media/doc/Grinberg\%200ctober\%20 2017\%20SFC\%20International\%20Tax\%20 Testimony\%20FINAL.PDF [hereinafter “Grinberg Senate Testimony"].

4326 USC $\S 960(d)(1)$.

44 New York State Bar Ass'n [NYSBA] Tax Section, Report No. 1394 on the GILTI Provisions of the Code 15 (May 4, 2018) www.nysba.org/ Sections/Tax/Tax_Section_Reports/Tax_ Reports_2018/1394_Report.html.

45 Given the FTC limitations imposed because of the GILTI FTC basket, in many situations the combined United States and foreign tax rate on CFC income will be well in excess of $13.125 \%$.

46 Indeed, neither Camp "Option C," as eventually proposed in HR 12014 when Representative Camp (Republican from Michigan) was chairman of the House Ways and Means Committee, nor the "Option $Y$ " and "Option Z" proposals released by Senator Baucus (Democrat from Montana) in 2013 when he was Chair of the Senate Finance Committee included a QBAI concept. Options $Y$ and $Z$ also used a partial exemption/partial full inclusion and foreign tax credit and expense disallowance mechanisms that may represent a more sensible and elegant way to address limitations on foreign tax credits and related expense allocation issues in a minimum tax regime than the mechanism ultimately adopted by the United States in 2017.

47 OECD, Addressing the Tax Challenges of the Digital Economy, BEPS Action 1: 2014 Deliverable, 112 (Sept. 16, 2014) (“The comprehensiveness of the BEPS Action Plan will ensure that, once the different measures are implemented in a co-ordinated manner, taxation is more aligned with where economic activities take place ... with the aim to put an end to the phenomenon of socalled stateless income."). In fact large U.S. firms based in Silicon Valley were achieving very low rates of tax on their foreign earnings under the old U.S. international tax regime. See European Commission, Report of the Commission Expert Group on Taxation of the Digital Economy (May 28, 2014). Consequently, European sovereigns took the position that special measures might be needed to solve this problem, unless the United States acted and imposed tax on the relevant firms. At the same time, all the large developed economies said they had no interest in shifting the balance between source and residence. France, Germany and the United Kingdom were particularly strong on this point.

48 For a balanced perspective on the broader question, see Wolfgang Schön, Ten Questions About Why and How to Tax the Digitalized Economy, 72 BULL. INTL. TAXN. 4/5, 79-81 (2018).

4926 USC §59A(a). Code Sec. 59A is effective for "base erosion payments" paid or accrued in taxable years beginning after December 31, 2017.

50 Code Sec. 59A(b)(1). Regular tax liability is defined in Code Sec. 26(b). The applicable credits are: the excess of "the credits allowed under this chapter against such regular tax liability" over, the sum of those "allowed under section 38 for the taxable year which is properly allocable to the research credit determined under section 41(a)"; and "the portion of the applicable section 38 credits not in excess of 80 percent of the lesser of the amount of such credits." Code Sec. 59A(b)(1)(B). Applicable Code Sec. 38 credits are defined in Code Sec. 59A(b)(4).

51 Code Sec. 59A(d). To be more precise, base erosion payments include any amount paid or accrued by the taxpayer to a foreign person which is a related party of the taxpayer and with respect to which a deduction is allowable, any amount paid or accrued by the taxpayer to a foreign person which is a related party of the taxpayer in connection with the acquisition by the taxpayer from such person of property of a character subject to the allowance for depreciation (or amortization in lieu of depreciation, reinsurance payments paid or accrued by the taxpayer to a foreign person which is a related party, and certain other payments to an expatriated entity which is a related party of the taxpayer which result in a reduction of the gross receipts of the taxpayer.

52 An item included in COGS can qualify as a base erosion payment if it is paid to certain inverted corporations or members of an expanded affiliated group of an inverted corporation. See Code Sec. $59 A(d)(4)$.

53 Code Sec. 59A(e)(3) treats those persons classified as a single employer under Code Sec. 52(a), with some modification, as a single taxpayer for the purposes of calculating gross receipts and base erosion percentage.

54 Regulated investment companies, real estate investment trusts, and $\mathrm{S}$ corporations are also exempt from the BEAT.

55 See NYSBA Tax Section, Report No. 1397 on Base Erosion and Anti-Abuse Tax 6 (July 16, 2018) www. nysba.org/Sections/Tax/Tax_Section_Reports/ Tax_Reports_2018/1397_Report.html. The report politely explains a number of the ways in which the BEAT as enacted functions poorly. Certain drafting errors associated with the current BEAT were deemed sufficiently problematic that the NYSBA felt compelled to write that "we believe that Treasury has authority to construe the provision logically in regulations to implement its legislative purpose, even in the absence of literal statutory support." 
56 Disregarded credits include foreign tax credits, $20 \%$ of low-income housing credits (Code Sec. 42(a)), $20 \%$ of renewable energy production credits (Code Sec. $45(\mathrm{a})$ ), and $20 \%$ of Code Sec. 46 investment credits allocable to the energy credit (Code Sec. 48). Research and Experimentation credits are not disregarded for purposes of establishing the hypothetical regular tax amount against which BEAT liability is in effect compared.

57 For examples and a formula, see generally Martin A. Sullivan, Economic Analysis: The BEAT in a Diagram and an Easy-to-Use Spreadsheet, TAX Notes (June 26, 2018) www.taxnotes.com/ tax-reform/economic-analysis-beat-diagramand-easy-use-spreadsheet.

58 Code Sec. 59A(i).

59 Part II of this paper draws heavily from a piece I recently published in the British Tax Review. Itai Grinberg, User Participation in Value Creation, BRITISH TAX REV. (forthcoming, 2018).

60 See, e.g., Michael P. Devereux \& John Vella, Implications of Digitalization for International Corporate Tax Reform (Oxford Univ. Centre for Business Taxation, Working Paper No. 17/07, 2017) www.sbs.ox.ac.uk/sites/default/files/Business_ Taxation/Docs/Publications/Working_Papers/ Series_17/WP1707.pdf; Allison Christians, Taxing According to Value Creation, 90 TAX NOTES INT'L 1379 (June 18, 2018); Joanna Hey, “Taxation Where Value is Created" and the OECD/G20 Base Erosion and Profit Shifting Initiative, 72 BULL. INTL. TAXN. 4/5 (2018).

61 Id.

62 See, e.g., HM Treasury, Corporate Tax and The Digital Economy: Position Paper Update, ๆ1.1 (Mar. 2018) https://assets.publishing.service. gov.uk/government/uploads/system/uploads/ attachment_data/file/689240/corporate_tax_ and_the_digital_economy_update_web.pdf [hereinafter "HMT Position Paper Update"]. A number of other reforms for the international tax system are also described by their advocates as reflecting the "value creation principle." One can best make sense of this development if one thinks of claiming the mantle of "value creation" as simply a claim that the reform being discussed should be the new multilateral norm.

63 European Commission Memorandum MEMO/18/214, Questions and Answers on Fair and Efficient Tax System in the EU for the Digital Single Market (Mar. 21, 2018) http://europa.eu/ rapid/press-release_MEMO-18-2141_en.htm.

64 See HM Treasury, Corporate Tax and The Digital Economy: Position Paper, П3.18 (Nov. 2017) https://assets.publishing.service.gov.uk/ government/uploads/system/uploads/attachment_data/file/661458/corporate_tax_and_the_ digital_economy_position_paper.pdf.

65 Communication from the Commission to the European Parliament and the Council: A Fair and Efficient Tax System in the European Union for the Digital Single Market, supra note 35, 9; OECD, Tax Challenges Arising from DigitalisationInterim Report 2018 (2018), supra note 3, para 47, at 28.
66 These businesses all exhibit what economists call "indirect network effects." D. Evans \& R. Schmalensee, MATCHMAKERS: THE NEW ECONOMICS of Multisided Platforms, 667 (2016). Indirect network effects exist where the value of the two-sided platform to one group of participants depends on how many members of a different group participate. Evans \& Schmalensee 25. Airbnb, Uber, and other businesses that intermediate transactions between groups of buyers of goods and services and groups of sellers of goods and services also share this feature that the value they provides increases as the number of participants on both sides of the platform increases.

67 See Lloyd's, Annual Report, 3 (2017) www.lloydsbankinggroup.com/globalassets/documents/ investors/2017/2017_lbg_annual_report_v3.pdf (approx. $85 \%$ of the risks insured by Lloyd's are non-UK risks).

68 See id. (only $13 \%$ of the capital in the Lloyd's market comes from the UK insurance industry).

69 Lloyd's, Lloyd's in the United States, 2 (2016) www.lloyds.com/lloyds-around-the-world/ americas/us-homepage/about-us.

70 Or, as HMT puts it user participation in reviewing and rating "services provided by third parties is crucial in regulating what appears on the platform and establishing an important trust mechanism for other users." HMT Position Paper Update, supra note 63 , ๆ 2.24.

71 See Lloyd's, Market Bulletin Y5170: Electronic Placement Mandate (Mar. 20, 2018) www.lloyds. $\mathrm{com} /$ market-resources/requirements-andstandards/electronic-placement.

72 See, e.g., Thibault Degrande, Frederic Vannieuwenborg, Sofie Verbrugge \& Didier Colle, Multi-Sided Platforms for the Internet of Things, 372-381 (2018).

73 For high-level discussion, see, e.g., PricewaterhouseCoopers, 2017 Automotive Industry Trends: The Future Depends on Improving Returns on Capital (2017) www.strategyand.pwc.com/media/file/2017Automotive-Industry-Trends.pdf.

74 Chin-Lung Hsu \& Judy Chuan-Chuan Lin, An Empirical Examination of Consumer Adoption of Internet of Things Services: Network Externalities and Concern for Information Privacy Perspectives, 62 COMPUTERs HUMAN BEHAV. 516-527 (2016). Additional projections suggest that 30 billion IOT devices by the year 2020 may be a conservative estimate. Global information firms estimate that the number of IoT devices connected worldwide already exceeds the thirty billion threshold, see IHS Markit, IOT TREND WATCH 2018, 4 (2018), and industry professionals have proposed that the number of devices "could approach 100 billion by the end of 2040." See Kathryn Cave, What Will the Internet Look Like in 2040?, IDG Connect (Sept. 8, 2015) www.idgconnect.com/ blog-abstract/10383/what-internet-look-2040.

75 Id. IHS Markit, IOT TREND WATCH 2018, 4 (2018).

76 See HMT Position Paper Update, supra note 63, ๆ3.7.
77 See HMT Position Paper Update, supra note 63, ๆ

78 European Commission, Proposal for a Council Directive on the common system of a digital services tax on revenues resulting from the provision of certain digital services, $\operatorname{COM}(2018)$ 148 final (Mar. 21, 2018) https://ec.europa. eu/taxation_customs/sites/taxation/files/ proposal_common_system_digital_services_ tax_21032018_en.pdf. European Commission, Proposal for a Council Directive laying down rules relating to the corporate taxation of a significant digital presence, $\operatorname{COM}(2018) 147$ final (Mar. 21, 2018) https://ec.europa.eu/taxation_ customs/sites/taxation/files/proposal_significant_digital_presence_21032018_en.pdf.

79 Id., at 89. See Paul Oosterhuis, Skadden Arps LLP, Residual Profit Allocation Proposal at Oxford University Summer Conference 2016 (June 27, 2016), available at www.youtube.com/watch?v= AjSxfUBMHnY\&list=PLtXf43N26Zids6PowkWDV7 oQo7HwoNspy\&index $=8 \& t=0$ s; see also Michael Devereux, Residual Profit Allocation Proposal at Brookings/Tax Policy Center Conference on "A Corporate Tax for the 21st Century" (July 14, 2016), available at www.taxpolicycenter.org/ sites/default/files/residual-profit-allocationproposal_2.pdf.

80 Analyzing the DBRMPA is also easier if one is familiar with formulary apportionment, salesbased formulary apportionment, and residual formulary apportionment. Those ideas, as well as the DBRPA, were described in a paper for the 2016 iteration of this conference authored by Joe Andrus \& Paul Oosterhuis, Transfer Pricing After BEPS: Where Are We and Where Should We Be Going, available at www.skadden.com/-/ media/files/publications/2017/03/transferpricing-afterbepswhereareweandwhereshould. pdf. Given the relative consistency of participation in the University of Chicago conference, in this Part I often assume familiarity with the excellent Andrus \& Oosterhuis paper. Readers wishing to refresh their memory of formulary apportionment, RFA and DBRPA as well as some of the issues that arise with those proposals are directed to pages 96 to 104 of that paper.

81 See Michael Devereux, supra note 80.

82 See Michael Devereux, supra note 80.

83 Michael C. Durst et al, Allocating Business Profits for Tax Purposes: A Proposal to Adopt a Formulary Profit Split, 9 FLA. TAX REV. 498, 540-541 (2009).

84 In contrast, RFA results in a single allocation (or perhaps a QBU by QBU allocation) of the average global profits of an entire multinational group.

85 Unlike RFA, DBRPA would also keep transfer pricing lawyers and economists productively employed.

${ }^{86}$ One industry where the difference between DBRPA and RFA could be important is pharmaceuticals. In that industry more than $40 \%$ of profits globally are generated in the United States, even though less than $40 \%$ of sales occur here.

87 Andrus \& Oosterhuis, supra note 81, 89-99. 
${ }^{88}$ Cf. Mitchell Kane, Transfer Pricing, Integration, and Synergy Intangibles: A Consensus Approach to the Arm's Length Standard, 6 WORLD TAX J. 282 (2014).

89 Oosterhuis \& Parsons, Destination-Based Income Taxation: Neither Principled nor Practical?, 71 TAX. L. REv. 515 (2018).

90 Indeed the term "marketing intangible" seems like a bit of a misnomer to me; the term "market intangible" might be more appropriate. Nevertheless, to avoid any confusion I use the term "marketing intangible" because it is the one that has been used most often in the current debate.

91 See, e.g., Rev. Rul. 79-285, 1979-2 CB 91.

92 See, e.g., Reg. \$1.167(a)-3 (1960); Gregory Beil, Internal Revenue Code Section 197: A Cure for the Controversy Over the Amortization of Acquired Intangible Assets, 79 U. MIAMI L. Rev. 731 (1995) (providing discussion of prior law regulations and the surrounding case law).

93 See Tax Treatment on Intangible Assets: Hearing Before the Comm. on Fin., United States Senate, on S. 1245, H.R. 3035, and H.R. 4210, 102d Cong., 2d Sess. 1, 3 (1992) (testimony of Hon. Fred T. Goldberg, Jr., Assistant Secretary for Tax Policy, Department of the Treasury and former IRS Commissioner) [hereinafter "Hearings"].

94 Jon D. Kitchel, A Tax Policy Analysis of Recent Legislative Proposals Regarding the Treatment of Goodwill, 92 TAX NOTES TOdAY 252-289 (Dec. 18, 1992).

95 U.S. Gen. Acct. Off., Tax Policy: Issues and Policy Proposals Regarding the Tax Treatment of Intangible Assets, 10 (1991) (report to the Joint Committee on Taxation).

96 Id. It is difficult to understate how serious the intangible asset categorization problem was thought to be in the period before the adoption of Code Sec. 197.

97 See Hearings, supra note 94.

98 For the method to function effectively, the transactions associated with a product line will also need to be accurately delineated. Depending on policy choices and the facts as issue, the DBRMPA may more fully import all the complexity associated with determining the appropriate level of aggregation and accurately delineating the transactions to be covered that arises in the transactional profit split method of the current transfer pricing guidelines than would a pure DBRPA.

99 OECD, Revised Guidance on the Application of the Transactional Profit Split Method: Inclusive Framework on BEPS: Action 10, OECD/G20 Base Erosion and Profit Shifting Project, ๆ2.123 (2018) www.oecd.org/tax/beps/revised-guidance-onthe-application-of-the-transactional-profitsplitmethod-beps-action-10.pdf [hereinafter "OECD Action 10"].

100 Id. $\mid 2.127$.

101 Id. $\mid 2.148$.

${ }^{102}$ Robert Guy Matthews \& Jeanne Whalen, Glaxo to Settle Tax Dispute with IRS Over US Unit for \$3.4 Billion, WALL St. J. (Sept. 12, 2006) www.wsj. com/articles/SB115798715531459461. At the time it represented the largest tax dispute in the history of the Internal Revenue Service, and it ended when GSK made the largest settlement payment in history.

${ }^{103}$ News Release, Internal Revenue Serv., IRS Accepts Settlement Offer in Largest Transfer Pricing Dispute (Sept. 11, 2006) www.irs.gov/ newsroom/irs-accepts-settlement-offer-inlargest-transfer-pricing-dispute.

${ }^{104}$ See, e.g., Gareth Green, The U.K. Reaction to the Glaxo Case, Tax Planning International Transfer Pricing, BNA (Nov. 2006).

${ }^{105}$ Cf. OECD Action 10, supra note 100, \$2.127. (" $[W]$ here the accurate delineation of the transaction determines that one party to the transaction performs only simple functions, does not assume economically significant risks in relation to the transaction and does not otherwise make any contribution which is unique and valuable, a transactional profit split method typically would not be appropriate since a share of profits ... would be unlikely to represent an arm's length outcome for such contributions or risk assumption.")

${ }^{106}$ Moreover, as the OECD correctly observes in the context of cost-based profit splitting factors in a transactional profit split, this approach "can be very sensitive to differences and changes in accounting classification of costs. It is therefore necessary to clearly identify in advance what costs will be taken into account ... and to determine the factor consistently among the parties." OECD Action 10, supra note 100, ఇ2.182.

${ }_{107}$ The Tax Court resolved part of the recent Amazon transfer pricing dispute using a technique akin to the one-sided DBRMPA method I describe here using a comparable uncontrolled transaction. Unlike in a TNMM, in the Amazon case all parties agreed that non-routine intangibles were controlled by both related parties to the transaction. Nevertheless, Judge Lauber's opinion adopted a comparable uncontrolled transaction methodology for determining the return that should be attributed to Amazon's website technology-the intangibles that would presumably be considered "production intangibles," in a DBRMPA, and treated the remainder of the residual return as allocable to a non-U.S. party.

${ }^{108}$ Wolfgang Schön, supra note 49, 79-81.

${ }^{109}$ The year 1978 was the high water mark for three factor apportionment at the state level in the United States. See, e.g., Walter Hellerstein, A US Subnational Perspective on the "Logic" of Taxing Income on a "Market" Basis, 72 BULL. INTL. TAXN. 4/5 (2018).

${ }^{110}$ See e.g., Charles E. McClure, Jr., The State Corporate Income Tax: Lambs in Wolves' Clothing, in THE ECONOMICS of TAXATION (Henry Aaron \& M. Boskin eds., 1980).

111 See Hellerstein, supra note 110.

112 For similar reasons, most academic observers agree that formulary apportionment employed internationally would probably be implemented (sooner or later) under a single factor salesbased formulary apportionment system.
${ }^{113}$ See, e.g., Alan Auerbach et al., Destination-Based Cash Flow Taxation, Oxford Univ. Ctr. For Bus. Taxation, Working Paper (Jan. 17, 2017) www.sbs. ox.ac.uk/sites/default/files/Business_Taxation/ Docs/Publications/Working_Papers/Series_17/ WP1701b.pdf.

114 See, e.g., Andrus \& Oosterhuis, supra note 81, 99. ("These issues may be novel in the income tax context, but not in the value-added tax context; the evolving thinking on these issues in the latter context can thus be a useful guide.")

115 In a credit-method VAT, registered businesses assess tax on taxable goods and services they sell each time they supply such a good or service to either a business or a consumer. Registered businesses are then permitted to reduce the amount of VAT they are liable to remit to the government by a credit equal to the amount of VAT paid to other registered businesses in purchasing business inputs (intermediate goods, services, plant and equipment, etc.). The credit eliminates the VAT on goods and services used by a registered business, but leaves in place the VAT on sales to final consumers. This mechanism ensures that the consumption of all goods and services subject to the VAT will be taxed once, but only once, generally at the consumer level. Imposing the VAT on a destination-basis requires a border adjustment. To eliminate the tax paid on an exported good by businesses at earlier stages in the production and distribution process, exporters receive a credit (and therefore perhaps a refund) for tax paid on their inputs in a credit-invoice method system, while no tax is assessed on their sales.

${ }^{116}$ The VAT mechanism works cross-border and is not equivalent to a tariff because the VAT credit mechanism then provides a credit to registered businesses (and not to consumers). The whole tax is passed on to consumers; businesses bear none of it. In contrast, in an income tax, businesses are intended to pay tax. As a result, the full credit mechanism is not an option in an income tax.

117 VAT on imports is generally collected at the same time as customs duties, although in some countries collection is postponed until declared on the importer's next VAT return.

${ }^{118}$ Of course, income taxes cannot provide expensing treatment in all cases while maintaining their status as income taxes.

119 Walter Hellerstein \& Michael Keen, Interjurisdictional Issues in the Design of a VAT, 63 TAX L. REV. 359 (2010).

${ }^{120}$ See Julie Roin, Can the Income Tax Be Saved? The Promised Pitfalls of Adopting Unitary Formulary Apportionment, 61 TAX L. REV. 169, 208 (2008) and Hellerstein, supra note 110, 9-12, for a discussion of these issues.

${ }^{121}$ Note also that to solve the problem of determining where globally-provided MNC to MNC services are "consumed," most VATs today generally follow the result achieved for purpose of corporate income tax chargeouts. It is obviously no answer to rely on the VAT to solve an income tax problem if the present law VAT solution is to rely on the income tax answer to solve that same problem. 
122 Clausing \& Avi-Yonah proposed a look-through rule for unrelated distributors in their single sales factor formulary apportionment proposal. Kim Clausing \& Reuven Avi-Yonah, Reforming Corporate Taxation in a Global Economy: A Proposal to Adopt Formulary Apportionment, Brookings Inst., June 2007.

${ }^{123}$ Andrus \& Oosterhuis, supra note 81, 101.

124 Andrus \& Oosterhuis, supra note 81, 100. See also Harry Grubert, Destination-Based Income Taxes: A Mismatch Made in Heaven, 69 TAX L. REV. 43, 55-56 (2015).

125 Some of these difficulties are discussed in Grubert, supra note 125, 57.

${ }^{126}$ Cf. OECD Action 10, supra note 100, ๆ \2.154-2.157 (describing the importance of aligning accounting rules in transactional profit splits).

127 Julie Roin, Can the Income Tax Be Saved? The Promised Pitfalls of Adopting Unitary Formulary Apportionment, 61 TAX L. REV. 169, 200 (2008).

${ }^{128}$ Roin's point was about formulary unitary taxation, but a close look reveals that most of the issues are related to unitary taxation rather than formulary approaches. Julie Roin, Taxation Without Coordination, 31 J. LEGAL STUD. S61, S78-S84 (2002) (detailing institutional impediments to development of a common income tax base).

${ }^{129}$ A "one-sided" valuation method DBRMPA could avoid the problems created by a "twosided" DBRMPA on the one hand and a "formulary" DBRMPA on the other, but in doing so approaches the result of a DBRPA. It does so with much more transfer pricing controversy embedded in order to get to that result.

${ }^{130}$ This idea also has some relationship to proposed special measure number five from the BEPS project's 2014 public discussion draft on Revisions to Chapter I of the Transfer Pricing Guidelines (Actions 8, 9 and 10). OECD, Discussion draft on revisions to Chapter I of the Transfer Pricing Guidelines (Including Risk, Recharacterisation and Special Measures) (2014) www.oecd.org/ctp/transfer-pricing/discussiondraft-actions-8-9-10-chapter-1-TP-Guidelinesrisk-recharacterisation-special-measures.pdf.

131 U.S. Dep't of the Treasury, General Explanations of the Administration's Fiscal Year 2017 Revenue Proposals (2016)

132 See, e.g., Dana Trier, International Tax Reform in a Second Best World: the GILTI Rules (discussion draft for this conference).

133 S. Comm. On Finance (minority), 115 $5^{\text {th }}$ Cong., Trump's Tax Law and International Tax: More Complexity, Loopholes and Incentives to Ship Jobs Offshore (2018). Note also that the articulated purpose of QBAI was to measure income from intangibles in an administratively simple way and exempt non-intangible returns from GILTI. A key motivating principle for the regime was that MNCs without high intangible returns should face an exemption system similar to those imposed by the countries of residence of most of their non-U.S. competitors. This policy rationale is coherent, but it is inapposite in a multilateral minimum tax regime.
134 Trier's paper also illustrates that a QBAI regime is not a natural fit with a German-style interest barrier of the type adopted by the United States in 2017. Trier's paper correctly treats this problem as a reason to question why the United States has chosen to exempt a return measured as a percentage of QBAI from its minimum tax, rather than a reason to abandon the Germanstyle interest barrier in favor of [describe Action 4 OECD proposal], which moved forward in the United States in the 2017 legislative process as proposed Code Sec. 163(n). In the end, Code Sec. 163(n) was excised from the U.S. legislation as enacted.

135 Treasury and the IRS will almost certainly smooth out many of the rough edges of the 2017 Act in regulations. But the statutory framework limits their ability to produce a clean system.

${ }^{136}$ Admittedly, as the thorough New York State Bar Report on the GILTI noted, the current GILTI regime contains elements of both a flat rate minimum tax on foreign income and an imperfect add-on to the prior-law subpart F regime. NYSBA Tax Section, Report No. 1394 on the GILTI Provisions of the Code (May 4, 2018), supra note 45. Determining whether Congress intended to enact a flat rate minimum tax or an add-on is probably unknowable. What is knowable is that the flat rate theory has a plausible rationale. In contrast, the GILTI as an imperfect add-on to the prior subpart $\mathrm{F}$ regime is normatively difficult to defend.

${ }^{137}$ Majority Staff of Permanent Subcomm. On Investigations, S. Comm. On Homeland Security and Governmental Affrs., $114^{\text {th }}$ Cong., Impact of the U.S. Tax Code on the Market for Corporate Control and Jobs, 2 (2015).

${ }^{138}$ Grinberg Senate Testimony, supra note 43. Importantly, the result appears to hold even with formerly U.S.-tax resident corporations that have substantial presence in the United States but change their country of tax residency. Nirupama Rao (formerly part of the Obama Administration CEA) has shown that former U.S. MNCs that undertake inversions subsequently develop higher shares of their employees and capital expenditures abroad after inversion, relative to similar firms that remain U.S. tax resident. Nirupama Rao, Corporate Inversions and Economic Performance, 68 NAT'L TAX J. 1073 (2015). As Rao's paper highlights, the changes in hiring and investment resulting from inversion are not attributable to the onetime effects on the data due to the inclusion of the foreign acquiring firm's existing workforce and investments. Rather, foreign shares of employment and investment are systematically higher two and more years after inversion, relative to the first year after inversion.

139 See Einkommensteuergesetz [EStG] [German Income Tax Act], §4j; see also, e.g., EY, German Parliament adopts legislation on limitation of tax deduction of royalties and tax exemption of restructuring gains (May 2, 2017).

140 See Elodie Lamer, Germany Wants Progress on BEPS, Minimum Effective Taxation, 91 TAX NOTES INT'L 1246 (Sept. 17, 2018).
141 See n. 40-41 and accompanying text.

142 U.S. Dep't of the Treasury, Unified Framework for Fixing Our Broken Tax Code, 9 (2017)

${ }^{143}$ Senate Finance Committee, Explanation of the Bill, 391 https://home.kpmg.com/content/dam/ kpmg/us/pdf/2017/11/tnf-sfc-explanation-ofbill-nov30-2017.pdf.

144 In an inbound base erosion regime intended to raise revenue, disaggregation of embedded intangibles could be required for cross-border payments associated with the supply in the United States of any good or service. Huge pressure would then exist for regulations attempting such a disaggregation to avoid overbreadth.

${ }^{145}$ It may be that such an agreement could not be reached with the EU in advance of March 29, 2019, the date for which Brexit is scheduled. Note also that from a U.S. perspective what would be important would be for an agreed defensive measure to be applied by all EU member states at the external EU border. If freedom of establishment constraints prevented application of a defensive measure by EU sovereigns in regard of payments to other EU member states, that limitation would not raise any fundamental U.S. policy concern.

146 Importantly, so long as the inbound minimum tax is intended as a defensive measure rather than a meaningful revenue raiser, principled answers with respect to the currently intractable problems raised by embedded intangibles and foreign corporations with no taxable nexus under current standards are simply not necessary. Given the technical challenges raised by these two issues, the ability to avoid them is a significant advantage.

147 In the case of Germany, an important question also arises as to whether there should be a commitment to block EU-level digital-only solutions.

148 More generally, the points above about coordination as to minimum standards for an outbound minimum tax regime would not require agreement as to all the details of the inbound minimum taxes (defensive measures) enacted by individual countries that are intended to backstop the outbound minimum tax regime.

${ }^{149}$ Henry Kissinger, Diplomacy 27 (1994). Not only was the United States the only country with the economic might to organize the international tax system of the capitalist world-its capacity to dictate international tax rules was part of a broader reality in which, in the Cold War period, the United States in effect organized most aspects of the economic and military structure of the noncommunist developed world. U.S. tax leadership, like U.S. political and economic leadership more broadly, was accepted in large part because of a threat the developed noncommunist world perceived; namely that without U.S. leadership the world might fall under Soviet domination.

150 Alternatively, one could perhaps imagine deemed presence rules combined with some minimum distributor-type returns meant to apply to all businesses. As with a formulary 
DBRMPA system, the principles underlying such a system and the international law sources that would stabilize it and ensure that any agreement would be respected are not clear. However, unlike a DBRMPA system, such a system (which arguably builds on Wolfgang Schön's digital investment concept could potentially be bolted on to the existing bilateral tax treaty system. C.f. n. 109 and accompanying text, supra.

This article is reprinted with the publisher's permission from the Taxes The Tax Magazine ${ }^{\circledR}$, a monthly journal published by Wolters Kluwer. Copying or distribution without the publisher's permission is prohibited. To subscribe to the Taxes The Tax Magazine ${ }^{\circledR}$ or other Wolters Kluwer journals please call 8004498114 or visit CCHCPELink.com. All views expressed in the articles and columns are those of the author and not necessarily those of Wolters Kluwer. 